\title{
Antimicrobial Compounds from Crustaceans and Their Applications for Extending Shelf-Life of Marine-Based Foods
}

\section{Oladipupo Odunayo Olatunde ${ }^{1}\left(\mathbb{D}\right.$, Soottawat Benjakul $\left.{ }^{1, *} \mathbb{(}\right)$, Ahmet Faruk Yesilsu'}

\author{
${ }^{1}$ Prince of Songkla University, Faculty of Agro-Industry, Department of Food Technology, Hat Yai, Songkhla, 90110, \\ Thailand. \\ ${ }^{2}$ Central Fisheries Research Institute, Trabzon, Turkey.
}

\section{Article History}

Received 26 January 2020

Accepted 24 April 2020

First Online 05 May 2020

\section{Corresponding Author}

Tel.: +6674286334

E-mail: soottawat.b@psu.ac.th

\author{
Keywords \\ Crustaceans \\ Peptides \\ Chitin \\ Carotenoids \\ Antimicrobials
}

\begin{abstract}
Antimicrobial-resistant microorganisms have become a major challenge for public health and food industries because of their fast adaptability and slow response to synthetic antimicrobials. Bioactive compounds from marine sources exert various biological roles including antioxidant, antimicrobial, anti-inflammatory, antihypertensive, and anticancer properties. Their advantage as an antimicrobial compound is gradually be exploited, particularly in marine-based foods (MBFs), which are highly perishable since they are abundant in proteins, lipids, and other nutrients. Also, the growing demand for fresh products with prolonged shelf-life is making the MBFs industry to urgently seek the effective methods for preservation of fresh or refrigerated MBFs. Crustaceans, which are invertebrates, are valuable source of essential nutrient based on their richness in protein, carbohydrate, minerals, lipids, and vitamins. Additionally, the by-product from the processing of crustaceans could be used as an alternative source of antimicrobials, which can be employed in MBFs as natural preservatives. This review therefore revisited the recovery of antimicrobials compounds such as antimicrobial peptides, carotenoids, and chitosan derivatives from crustaceans. The uses of these crustacean antimicrobials in extending the shelf-life of MBFs are also discussed.
\end{abstract}

\section{Introduction}

Living organisms captured from the marine environment and used as food are regarded as seafood or other known as marine-based foods (MBFs) (Hosomi, Yoshida, \& Fukunaga, 2012). MBFs may consist of several species of mollusks, fish, echinoderms, seaweed or macroalgae, crustaceans, which are rich sources of fat, protein, vitamins and minerals (Olatunde, Benjakul, \& Vongkamjan, 2018). The requirement of these aforementioned nutrients for normal body functions and their beneficial effects on the human physiological functions as well as the brain and nervous system have been emphasized (Liao \& Chao, 2009). MBFs are considered as essential in human diet based on dietary analysis, (Hu et al., 2009; Richards \& Trinkaus, 2009). The awareness of the nutritional benefits of MBFs has brought about an increase in the rate of consumption. In 2017, the per capita consumption of MBFs worldwide was $20.5 \mathrm{~kg}$, indicating an increase from $19.9 \mathrm{~kg}$ recorded in 2014 (Ye et al., 2017). Microbial spoilage in MBFs, associated with changes in both chemical and sensory properties as well as safety has continued to pose the threat in seafood industries (Gram \& Huss, 1996).

According to WHO (2013), the treatment and/or control of diseases, spoilage, poisoning or infections caused by microorganisms, particularly those showing resistance to regular antibiotics/drugs is regarded as a public health goal and a major challenge to food 
industries. The decreasing therapeutic effect of conventional antimicrobials is associated with the improper use and inappropriate dose of these compounds, which allow the microorganisms to develop the resistance toward them over time (León-Calvijo et al., 2015). Over the years, attention has been geared towards the searching of antimicrobial compounds, particularly from natural sources, which can be applied as a substitute for controlling both pathogenic and spoilage microorganisms. Several antimicrobial compounds from natural sources, particularly from marine organisms and plant, have shown excellent inhibition against antibiotic-resistant microorganisms (Mahlapuu, Håkansson, Ringstad, \& Björn, 2016).

Crustaceans including lobster, crab, shrimp, crayfish, and krill contributed majorly to the total aquaculture production (FAO, 2018). Economically, crustaceans are highly important across the globe (FAO, 2014; Gonçalves \& de Oliveira, 2016). For instance, global shrimp production, currently at roughly $6 \mathrm{MMT}$ (million metric tons), is expected to increase by $4.8 \%$ between the years 2016 and 2019 (Gulzar \& Benjakul, 2019). Asia is one of the most prominent consumers and producers of shrimp (Anderson, Valderrama, \& Jory, 2013). In recent years, Thailand among the Asian countries has held a major share (Gulzar \& Benjakul, 2019; Raju \& Benjakul, 2020). For instance, annual production of shrimp has reached 4.8 million tonnes in 2016 (FAO, 2018). By-products are generated during the processing of crustaceans, which can be further transformed to other products with varying bioactivities and increased value (Gulzar \& Benjakul, 2019; Sinthusamran, Benjakul, Kijroongrojana, Prodpran, \& Agustini, 2018). Thus, this review gathers the recent information on the antimicrobial compounds from crustaceans with major focus on the extraction and bacterial inhibitory activities. The applications of these antimicrobials in extending the shelf-life of MBFs are also discussed.

\section{Microbial Spoilage in Marine-Based Foods}

Spoilage in MBFs is primarily due to the proliferation as well as metabolism of microorganisms, particularly specific spoilage microorganisms (SSOs), which were responsible for the production of unwanted compounds, e.g. ketones, alcohols, organic acids, biogenic amines, histamine, aldehydes, sulphides and putrescine (Kuley et al., 2017). Microorganisms derived the energy used for their growth and produce various metabolites from substances having low-molecular weight such as small peptides, free amino acids and sugars available in the fish muscle (Olatunde et al., 2018). Also, the enzymes produced by some bacteria including psychrotolerant Enterobacteria, Aeromonas spp, Vibrio spp and Shewanella putrefaciens have been associated with the formation of trimethylamine (TMA) mediated by the reduction of trimethylamine oxide (TMAO), which contributes greatly to fishy odor in MBFs
(Lidbury, Murrell, \& Chen, 2014). Enzymatic and bacterial breakdown of nucleotides such as inosine monophosphate or inosine has been reported to produce hypoxanthine in MBFs (Varlet \& Fernandez, 2010; Visciano, Schirone, Tofalo, \& Suzzi, 2012). Bitter taste in MBFs has been attributed to the combined production of TMA and hypoxanthine (Tikk et al., 2006).

Several factors such as type of seafoods and products, preservation methods, packaging material, storage condition, atmosphere, and salt content, etc. influence the growth of SSOs in MBFs (Gram \& Dalgaard, 2002). However, geographic location, method of fishing, and the fishing ground are factors determining bacterial microbiota of fishes (Ghaly, Dave, Budge, \& Brooks, 2010). Based on the different abilities of bacteria to tolerate preservation or treatment, the microflora of MBFs may vary (Bekaert, Devriese, Maes, \& Robbens, 2015). In general, psychrophilic bacteria are mainly associated with spoilage in refrigerated or chilled MBFs.

Most SSOs responsible for spoilage in MBFs are Gram-negative (G-) bacteria such as Pseudomonas, Shewanella putrefaciens, Aeromonas, Flavobacterium, Moraxella, Acinetobacter, Photobacterium, and Vibrio (Sivertsvik, Jeksrud, \& Rosnes, 2002). SSOs including Photobacterium phosphoreum, Shewanella and Pseudomonas were found as the main spoilage bacteria in MBFs (Gram \& Dalgaard, 2002). Pseudomonas and Shewanella were predominant spoilage microorganisms in Asian sea bass slices packaged in air and that packaged under argon based modified atmosphere packaging (MAP) (Olatunde, Benjakul, \& Vongkamjan, 2019). Pseudoalteromonas spp., Luteimonas spp., Psychrobacter spp., Aliivibrio spp. and Pseudomonas spp. were identified as the main SSOs responsible for spoilage in Norway lobster (Nephrops norvegicus) (Bekaert et al., 2015). Reynisson et al. (2009) reported Photobacterium phosphoreum as the predominant SSOs in North-Atlantic cod (Gadus morhua) stored at refrigerated temperature.

Microflora of MBFs is constantly changing during extended storage or transportation/ processing, which allows Gram-positive ( $\mathrm{G}+$ ) bacteria to cause the spoilage (Al Bulushi, Poole, Barlow, Deeth, \& Dykes, 2010). Lactic acid bacteria (LAB) and $P$. phosphoreum were also responsible for fish spoilage (Dalgaard, 2000). Spoilage in MBFs was attributed to $\mathrm{G}+$ bacteria, such as Staphylococcus, Corynebacterium, Micrococcus, Clostridium, Bacillus, Streptococcus, and Brochothrix thermosphacta (Fall, Leroi, Cardinal, Chevalier, \& Pilet, 2010). Therefore, both G- and G+ bacteria contribute to the spoilage of MFBs.

\section{Antimicrobial Compounds}

An antimicrobial is an agent that can inhibit the proliferation of microorganisms. They could either be bacteriostatic (prevent/retard the bacteria growth or metabolism) or bactericidal (inactivate/kill bacterial cell), depending on its source, concentration, and 
efficiency (Olatunde et al., 2018). The mechanisms of antimicrobial compounds against both G+ and Gbacteria can be varied. However, the sensitivity between $\mathrm{G}+$ or $\mathrm{G}$ - bacteria toward antimicrobial compounds differs. G+ bacteria show more resistivity towards antimicrobial compounds in comparison with G- bacteria. This is mainly owing to the several layers of peptidoglycan in the outer membrane of $\mathrm{G}+$ bacteria as compared to the single layer of peptidoglycan in Gcounterpart (Abdollahzadeh, Rezaei, \& Hosseini, 2014). In general, the major mechanism of several antimicrobial compounds is their interaction with the outer membrane of a microbial cell, forming pores or blocking membrane ion gradients, consequently leading to cell death (Moravej et al., 2018). However, mechanism or mode of action of different antimicrobial compounds can be differentiated toward the target microorganisms.

Microorganisms are developing the resistance to synthetic antimicrobial compounds (Mantravadi, Kalesh, Dobson, Hudson, \& Parthasarathy, 2019), therefore posing as worldwide threats for food preservation and safety (Hayashi, Bizerra, \& Da Silva Junior, 2013). To circumvent this challenge, attention has been recently shifted to natural antimicrobials, which have shown promising bacteriostatic or bactericidal impacts. Medicinal plants, marine, and terrestrial organisms, including bacteria and fungi have been demonstrated as potential natural sources of antimicrobial compounds with high activity (Hayashi et al., 2013).

\section{Antimicrobial Compounds in Crustaceans}

Several compounds in crustaceans such as bioactive peptides, chitosan and its derivatives as well as carotenoids/ astaxanthin have been proven to have high antimicrobial properties against several microorganisms.

\section{Antimicrobial Peptides and Extracts}

Over the years, attention has been geared towards the development of antimicrobials, particularly from natural sources, with no evidence of inducing resistance in pathogenic microorganisms. As a consequence, those natural antimicrobials could be used as an alternative for bacteria inactivation. Among the natural antimicrobial agents, antimicrobial peptides (AMPs) have shown great potential in preventing damages caused by antibiotic-resistant microorganisms (Mahlapuu et al., 2016). AMPs, also known as hostdefense peptides (HDP), are present in all forms of life, in which several forms are reported in archaea (4), fungi (13), bacteria (200), vertebrates and invertebrates (2159) and plants (343) (Kumar, Kizhakkedathu, \& Straus, 2018). AMPs are short-chain peptides with positive charge and varying amino acid sequence. The amphipathic fragment of proteins isolated from plant or animal kingdom, showed the promising antimicrobial properties (León-Calvijo et al., 2015). G+ bacteria, Gbacteria, fungi, parasites, and viruses have been inhibited by AMPs (Bahar \& Ren, 2013).

The selection of AMPs in clinical treatments or foods is largely due to their speed of microbial inactivation action, high selectivity, and difficulty of microorganisms in developing resistance against them (Bradshaw, 2003). AMPs are sometimes regarded as HDP (Riedl, Zweytick, \& Lohner, 2011), anionic antimicrobial peptides/proteins (Harris, Dennison, \& Phoenix, 2009), cationic amphipathic peptides (Groenink, Walgreen-Weterings, van't Hof, Veerman, \& Nieuw Amerongen, 1999), $\alpha$-helical antimicrobial peptides (Huang, Huang, \& Chen, 2010), cationic host defense peptides (Brown \& Hancock, 2006), cationic AMPs (Bradshaw, 2003). Commercially, many AMPs, particularly produced from microorganisms such as bacteriocins, ambicin (nisin), polymixin B and gramicidin $S$ have been applied for clinical purposes (Yang, Lin, Sung, \& Fang, 2014) or food treatment (Olatunde et al., 2018), in which high microbial inhibition is attained. However, they are associated with the high cost of production, and low yield (Juturu \& Wu, 2018), To circumvent these limitations, attention has been shifted to AMPs produced from marine sources, particularly from their processing by-products.

Marine animals are a good source of AMPs such as pardaxin, misgurin, cathelicidins, defensins, hepcidin, NK-lysin, piscidin with very high promising activities (Shin et al., 2017). The production of peptides from byproducts of marine-based food processing is generally carried out by chemical (acid and alkaline), enzymatic and microbial hydrolysis (Harnedy \& FitzGerald, 2012). Enzymatic hydrolysis has been commonly used as the fast method for producing peptides with varying bioactivities including antimicrobial activity. Proteins are gradually cleaved by proteases from different sources (Figure 1). Due to the differences in specificity toward proteinaceous substrate, the resulting peptides can be varied. Additionally, the antimicrobial activity of AMPs can be different. Ennaas, Hammami, Beaulieu, and Fliss (2015) reported varying antimicrobial activities of AMPs derived from Atlantic mackerel via enzymatic hydrolysis with Neutrase, Protamex, papain, and Flavourzyme against Escherichia coli MC4100 and Listeria innocua HPB13. Different fractions of AMPs extracted from Nile tilapia (Oreochromis niloticus) byproduct, which had leucine, lysine, glutamic acid, arginine, aspartic acid, alanine and glycine as the most dominant amino acids, showed varying antimicrobial properties against Edwardsiella tarda, Yersinia ruckeri, and Bacillus megaterium (Robert et al., 2015). The presence of residual chemicals and generation of some toxic substances in AMPs produced using chemical hydrolysis has limited the application of such AMPs for food application in spite of the fast process (Olatunde et al., 2018). 


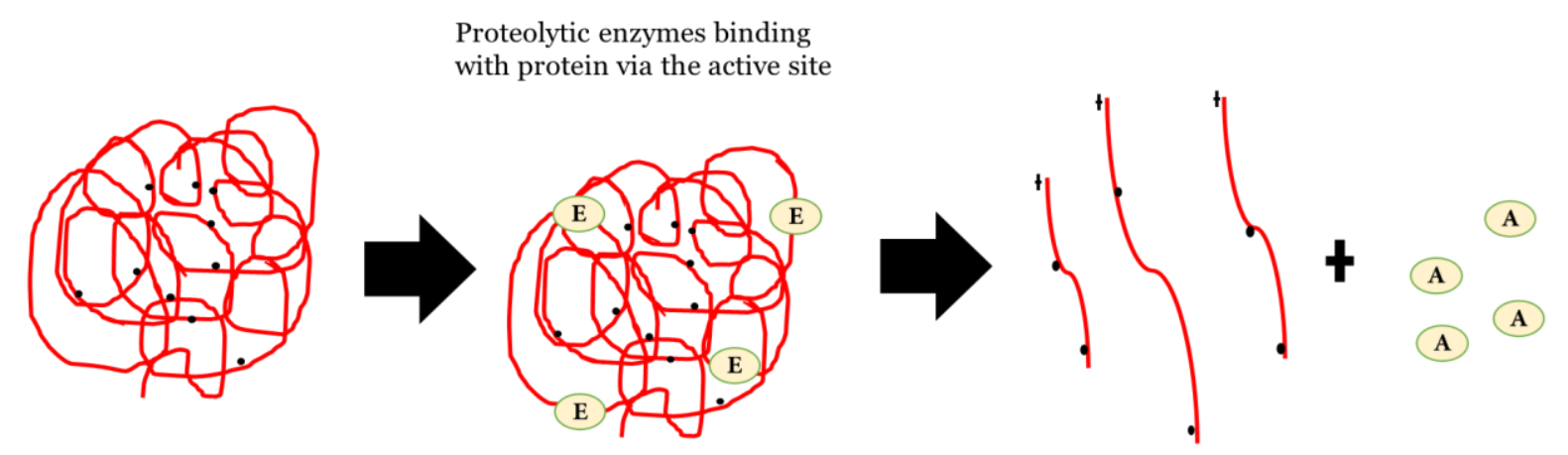

Globular protein from crustaceans having both hydrophobic and hydrophilic amino acid
Enzymatic hydrolysis
Positively charged antimicrobial peptide and varying molecular weight.
Free amino acids

- Hydrophobic domain/ residue

Figure 1. Enzymatic production of antimicrobial peptides from crustaceans

\section{Antimicrobial Properties}

Attention has been geared towards the antimicrobial properties of AMPs extracted from several sources as well as secondary metabolites (bacteriocins and antibiotics) generated during the fermentation of different food matrices (Linares et al., 2017). AMPs from crustacean processing byproducts have been rarely studied, as compared to other bioactivities such as antioxidants, anti-inflammatory and anticancer. Generally, AMPs have $<50$ amino acids (AAs) with a molecular weight $<10 \mathrm{kDa}$, in which half of the AAs are hydrophobic in nature (Najafian \& Babji, 2012; ZamoraSillero, Gharsallaoui, \& Prentice, 2018). Because of the charge and size of AMPs, they interact rapidly with negatively charged domain of $\mathrm{G}+$ and $\mathrm{G}$ - bacteria cells and inactivate them (Zhang, Zou, Manchu, Zhou, \& Wang, 2008). The applications of AMPs have gained massive interests in treating illness and diseases as compared to conventional antibiotics due to their high rate of bacterial inactivation and abilities to inhibit antibiotic-resistance microorganisms (Najafian \& Babji, 2012).

The mechanisms of antimicrobial properties for AMPs vary, dependent on the size of the peptide, the amino acid sequence, flexibility and hydrophobic residues (Jenssen, Hamill, \& Hancock, 2006). The interaction of AMPs with the microbial cytoplasmic membrane is the first mode of action for inactivating the microbial cells (Perez Espitia et al., 2012). However, cationic AMPs can also exhibit antimicrobial activities via modification of the hydrophobicity ratio or the net charge (Sila et al., 2014). Pores are formed on the microbial cells via the interaction between AMPs and microorganisms. Furthermore, these interactions could lead to the blockage of the membrane ion gradients, thereby causing microbial destruction or death (Najafian \& Babji, 2012). Microorganisms are also inactivated by the ability of the AMPs in modifying the microbe's cellular metabolisms (Wald, Schwarz, Rehbein,
Bußmann, \& Beermann, 2016). The different modes of antimicrobials action by AMPs have been summarized in Figure 2.

AMPs from crustaceans have been studied. Zhao, Yin, Liu, and Cao (2013) purified AMPs from protein hydrolysate $(\mathrm{PH})$ obtained from Antarctic krill using Protamex. The peptide had a molecular weight (MW) ranging from 245 to $709 \mathrm{Da}$ and inhibited the proliferation of Staphylococcus aureus [minimum inhibition concentration $(\mathrm{MIC})=5.0 \mathrm{mg} / \mathrm{mL}$ ]. The mechanism of action was attributed to the rupture of the outer membrane of bacteria, increased cell membrane permeability and the loss of intracellular substances, which led to the death of S. aureus (Zhao et al., 2013). G+ bacteria, including Listeria innocua CECT 910, Lactobacillus helveticus DSM 20075, and S. aureus CECT 240, and G- bacteria including Escherichia coli CECT 515, Citrobacter freundii ECT 401, and Pseudomonas fluorescens CECT 4898, were inhibited by $\mathrm{PH}$ derived from shrimp processing by-products prepared with the aid of an enzyme produced from Enterococcus faecalis DM19 and heated in the presence of glucosamine (800 $\mathrm{mg}$ ) at $100{ }^{\circ} \mathrm{C}$ (Djellouli, López-Caballero, Arancibia, Karam, \& Martínez-Alvarez, 2019). Some indigenous AMPs in the marine animal also have antimicrobial activity. Imjongjirak, Amparyup, and Tassanakajon (2011) identified 2 novel peptides (GRPSp and arasinlikeSp) from the hemocytes of Scylla paramamosain, which showed potent inhibition against Vibrio harveyi, Aerococcus viridans, V. anguillarum, and Micrococcus luteus.

The extract from crustacean is another source of antimicrobials peptides with varying properties and activities. Hemolymph extracted from male and female brachyuran crabs, Liagore rubromaculata, possessed strong antibacterial activity against Salmonella typhi, $V$. cholerae, E. coli, Ent. Faecalis, K. oxytoca, and Proteus vulgaris; the antimicrobial activity was highest toward Proteus vulgaris and Ent. faecalis for female and male crabs, respectively (Priya, Ravichandran, \& Jawaharlal, 2014). B. Chen et al. (2015) reported that sphistin 


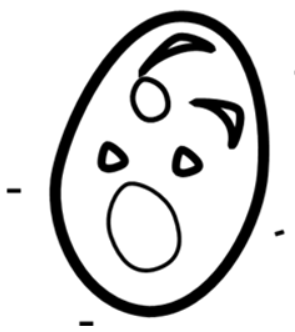

Negatively charged outer cell membrane, such as lipopolysaccharides in Gram-negative bacteria or

lipoteichoic acid on the surface of Gram-positive bacteria

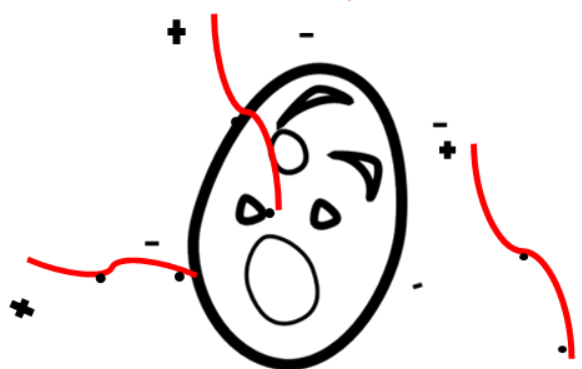

Positively charged peptide, with hydrophobic amino acid.
Electrostatic interaction between peptides and bacteria, which removes the native divalent cations $\left(\mathrm{Mg}^{2+}, \mathrm{Ca}^{2+}\right)$ from the cell surface, thus destabilizing the outer membrane and facilitating the entry of the peptide and subsequent peptide contact with the cytoplasmic membrane, a process known as autopromoted uptake.

Hydrophobic-hydrophilic interaction between the hydrophobic cell wall and the hydrophobic domain of peptides.

Figure 2. Mechanism of microbial inactivation by antimicrobial peptides

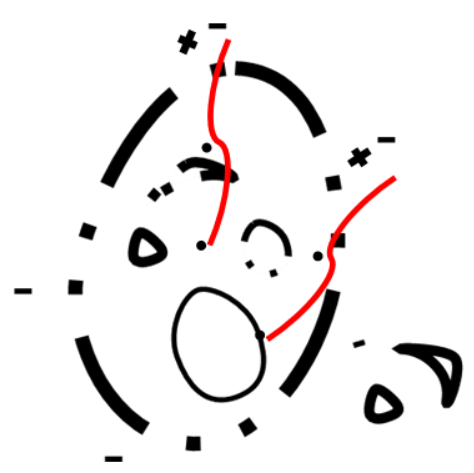

Disruption of cell membrane wall, thus provoke internal osmotic imbalances and consequently inhibit the growth of microorganisms.

Penetration of the peptide into the cell, which induced stress and consequently death. 
derived from the $\mathrm{N}$-terminus of crab histone $\mathrm{H} 2 \mathrm{~A}$ found in the hemolymph of Scylla paramamosain showed great inhibition towards a number of G- and G+ bacteria, in which inhibition was highest for Micrococcus luteus, Micrococcus lysodeikticus Fleming, Corynebacterium glutamicum, S. aureus, B. subtilis, P. fluorescens, Shigella flexneri, and $P$. stutzeri. Also, sphistin was able to inhibit yeast (Pichia pastoris and Candida albicans). The mechanism of action was attributed to the loss of the cellular contents and disruption of the cell outer membrane induced by sphistin (B. Chen et al., 2015).

\section{Chitosan and its Derivatives}

Chitin ( $\beta$-(1-4)-poly-N-acetyl-D-glucosamine) is mainly prepared from the exoskeletons of crustaceans (Kandra, Challa, \& Jyothi, 2012), although chitin with varying amounts has been reported in numerous insects, mushrooms, fungi and worms (Arcidiacono \& Kaplan, 1992). It occurs naturally as the ordered microfibril and serves as the main structural component in the exoskeletons of crustacean (Elieh-Ali-Komi \& Hamblin, 2016). Due to high porosity, biodegradability, predictable degradation rate, non-toxicity to cells, bioabsorbability, biocompatibility, and structural integrity, the applications of chitin in various fields have gained more attention (Elieh-Ali-Komi \& Hamblin, 2016; Kandra et al., 2012). Four major steps, which include 1) demineralization using EDTA, $\mathrm{HCl}$ or formic acid, 2) deproteinization using proteases or $\mathrm{NaOH}$, 3) decolorization using solvent and 4) treatment with an oxidizing agent such as sodium hypochlorite, chlorine or hydrogen peroxide or their combination are involved during the extraction of chitin (Lodhi et al., 2014). However, due to its insolubility, it cannot be widely used and its exploitation is limited.

Chitosan ( $\beta$-(1-4) linked 2-amino-2-deoxy- $\beta$-Dglucopyranose), which is prepared by the deacetylation of chitin using either chemical process (under strong alkaline condition) or enzymatic hydrolysis (chitin deacetylase) is the most widely used derivative of chitin (Elieh-Ali-Komi \& Hamblin, 2016; Islam, Bhuiyan, \& Islam, 2017). Chitosan ( $N$-deacetylated derivative of chitin) is formed when acetamide group in chitin is converted by the aforementioned processes into primary amino groups (Islam et al., 2017). However, deacetylation is not a complete process as deacetylated chitin or chitosan still contains few acetamide groups (Dutta, Dutta, \& Tripathi, 2004). The deacetylation process used determines the distribution of acetyl groups as well as the degree of deacetylation (DD) of chitosan. These two factors influence the reactivity, biodegradability, solubility and other properties of the resultant chitosan (Islam et al., 2017; Lodhi et al., 2014; Rinaudo, 2006). Chitosan is insoluble in water due to its high MW, however it can be dissolved in slightly acidic condition ( $1 \%$ formic or acetic acid), which is associated with the protonation of the $\mathrm{NH}_{2}$ group of the $\mathrm{D}$ glucosamine repeat unit at the $\mathrm{C}-2$ position (Rinaudo,
2006). Chitosan has been widely modified chemically, enzymatically, and physically to augment its applicability and solubility (Olatunde et al., 2018).

The production of chitooligosaccharide (degree of polymerization of $\leq 20$ and an average $\mathrm{MW}$ of $<3900 \mathrm{Da}$ ) and glucosamine via the hydrolysis of chitosan has gained increasing interest, due to the improved properties of those derivatives. Several methods including enzymatic methods using non-specific enzymes (lipase, protease, lysozyme, amylase cellulose, etc.) or specific enzymes (chitinase, chitosanase, etc.), chemical methods (hydrogen peroxide oxidation, acid hydrolysis), electrochemical methods or physical methods (ultrasonic treatment, ultraviolet radiation and microwave treatment) have been employed for the production of chitooligosaccharide (COS) (Liang, Sun, \& Dai, 2018). Fully deacetylated $\operatorname{COS}$ and partially acetylated COS with MW between 0.2 and $1.2 \mathrm{kDa}$ were produced during the enzymatic hydrolysis of chitosan using neutrase and chitinase from Trichoderma harzianum, respectively (Santos-Moriano et al., 2019).

\section{Antimicrobial Properties}

Chitosan and its derivatives possess antibacterial properties against various spoilage and pathogenic microorganisms. Chitosan and its derivatives generally exhibit bacteriostatic rather than bactericidal activities (Goy, Britto, \& Assis, 2009). Several models for the antimicrobial action of chitosan and its derivative have been proposed. Those include 1) the interaction between chitosan molecules (dissolved in acidic solution), which is positively charged and microbial cell membranes, which is negatively charged, mediated by electrostatic forces between negatively charged residues and protonated $\mathrm{NH}_{3}{ }^{+}$groups, presumably by competing with ions, particularly $\mathrm{Ca}^{2+}$ for electronegative sites on the membrane surface (Goy et al., 2009; Olatunde et al., 2018), 2) the invasion of chitosan into the nuclei of the microorganism, thereby leading to inhibition of protein synthesis and messenger ribonucleic acid (mRNA) (Sebti, Martial-Gros, CarnetPantiez, Grelier, \& Coma, 2005), and 3) the suppression of spore via their binding to essential nutrients and the chelation of metals (Figure 3) (Goy et al., 2009). S. aureus of clinical origin is inhibited by low MW chitosan (119.48 kDa), prepared by chemical hydrolysis (thermoalkaline hydrolysis) of chitin dissolved in $1 \%$ acetic acid (Escárcega-Galaz, López-Cervantes, Sánchez-Machado, Brito-Zurita, \& Campas-Baypoli, 2017). Unmodified chitosan and chitosan modified with different flavonoids such as flavanols, flavonols, flavones, flavanones, and isoflavones inhibited the proliferation of $B$. subtilis, $S$. aureus, $K$. pneumonia, and $P$. aeruginosa. Greater activity was recorded for flavonoid-functionalized chitosan as compared to the unmodified counterpart (Sousa, Guebitz, \& Kokol, 2009).

Low MW chitosan (5.06 kDa, DD=90\%) had higher inhibition against Salmonella typhimurium, E. coli, and 
A

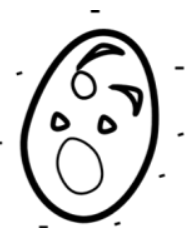

Negatively charged microbial cell membrane.

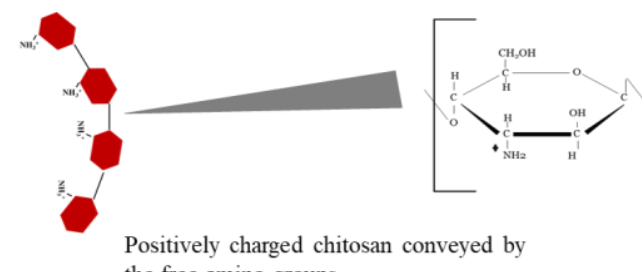

Positively charged chitos.
the free amino groups.

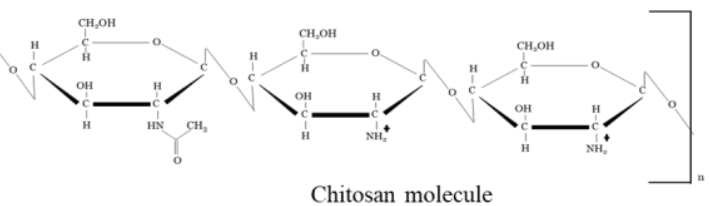

Chitosan molecule

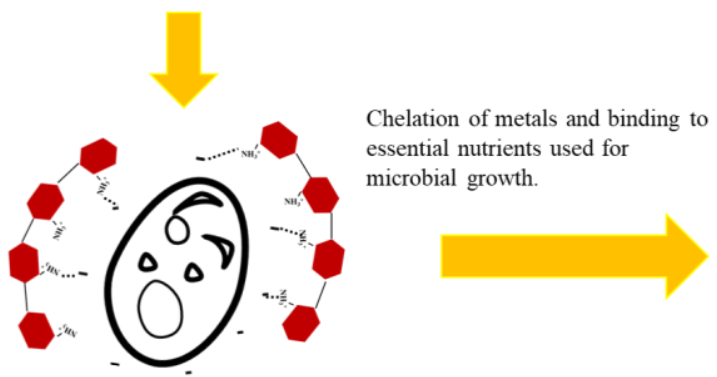

The interaction between positively charged chitosan

molecules and negatively charged microbial cell membranes

mediated by the electrostatic forces between the protonated

amino groups and the negative residues.

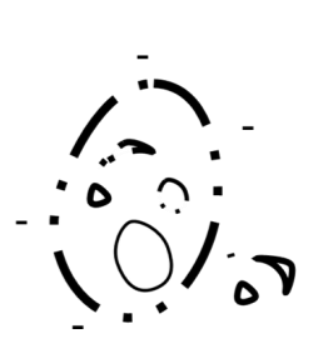

Changes in the properties of membrane wall permeability, thus provoke internal osmotic imbalances and consequently inhibit the growth of microorganisms.

The hydrolysis of the peptidoglycans in the microorganism wall, leading to the leakage of intracellular electrolytes such as potassium ions and other low molecular weight proteinaceous constituents.

The inhibition of mRNA and protein synthesis via the permeation of chitosan into the nuclei of the microorganism.

\section{B}

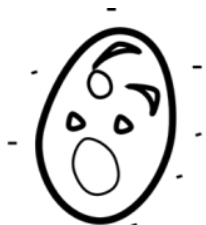

Negatively charged microbial cell membrane.

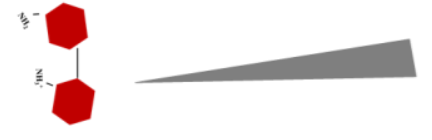

Low molecular weight chitooligosaccharide

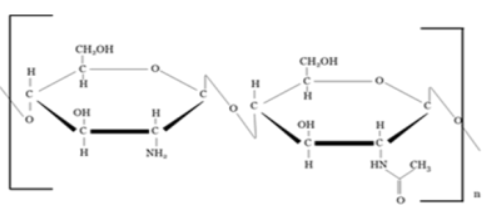

Chitooligosaccharide molecule

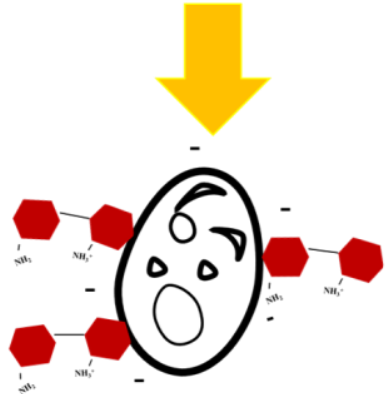

Binding of the chitooligosaccharide molecules with the microbial lectins thereby penetrating to the cell. Chelation of metals and binding to essential nutrients used for microbial growth.

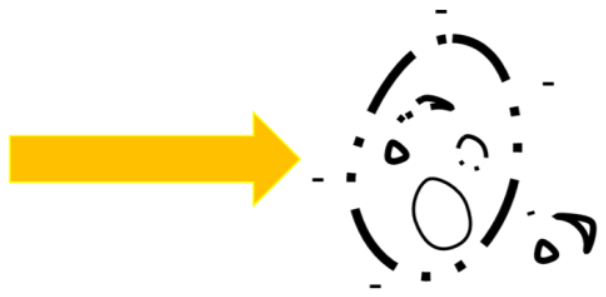

Changes in the properties of membrane wall permeability, thus provoke internal osmotic imbalances and consequently inhibit the growth of microorganisms.

The hydrolysis of the peptidoglycans in the microorganism wall, leading to the leakage of

intracellular electrolytes such as potassium ions and prer low molecular weight proteinaceous constituents. The penetration of chitooligosaccaharide into bacterial cytoplasm which causes the modification of biomolecules such as mRNA, DNA, proteins, etc.

Figure 3. Mechanism of microbial inactivation by chitosan (A) and chitooligosaccharide (B)

Salmonella enteritidis as compared to high $\mathrm{MW}$ counterpart (14.3 and $41.1 \mathrm{kDa}, \mathrm{DD}=90 \%$ ) (Laokuldilok et al., 2017). Nevertheless, Batista, Dantas, Santos, and Amorim (2011) documented the antimicrobial properties of high MW chitosan (CSH) and medium MW chitosan (CSM) with DD of $85 \%$ and $90.43 \%$, respectively, dissolved in acetic acid (0.25\%), against Lactobacillus casei ATCC 7469, S. aureus $319 \mathrm{U}$ and E coli ATCC 25922. Although the increased activity was attained with higher chitosan concentration, CSM exhibited greater inhibition when compared to CSH. The antibacterial action of CSM against $E$. coli was the result of the damage of the cell wall membrane and the loss of cellular components (Batista et al., 2011). The proliferation of Escherichia coli (NCTC 9001) and Staphylococcus aureus (NCTC 8532) was inhibited by chitosan with different $\mathrm{MW}$ (628, 591 and 107 kDa, 
having DD in the range of $80-85 \%)$, which was all dissolved in 1\% (v/v) acetic acid (Fernandes et al., 2008).

The antimicrobial properties of modified chitosan have also been demonstrated. $\mathrm{G}+$ bacteria (S. aureus RCMB 010028 and Streptococcus pneumonia RCMB 010010), G- bacteria (E. coli RCMB 010052), and fungi (Candida albicans RCMB 05036, Geotricum candidum RCMB 0509, and Aspergillus fumigatus RCMB 02568) were inhibited markedly by Schiff base modified chitosan (acrylonitrile) as compared to unmodified chitosan (Sabaa, Elzanaty, Abdel-Gawad, \& Arafa, 2018). Chitosan modified by grafting borneol 4-formylbenzoate using a stable Schiff base bond, in which the process yielded borneol-modified chitosan (BMC) inhibited the growth of E. coli, B. subtilis, and Aspergillus niger (Xin et al., 2020). Pyricularia grisea, Fusarium oxysporu, and Alternaria solani were all inhibited by chitosan nanoparticles, which was prepared by the addition of anionic proteins isolated from Penicillium oxalicum culture to chitosan solutions (Sathiyabama \& Parthasarathy, 2016). Y. Chen et al. (2016) documented enhanced antimicrobial properties against Staphylococcus aureus ATCC6538 and Escherichia coli ATCC25922 for chitosan modified with sulfobetaine and quaternary ammonium. The antimicrobial properties of native chitosan against $P$. aeruginosa, $E$. coli, $B$. cereus, S. aureus, Salmonella sp., and Candida albicans were boosted after chitosan was modified with indole-3carboxaldehyde and 4-dimethylaminobenzaldehyde using the Schiff base method (Hassan, Omer, Abbas, Baset, \& Tamer, 2018).

COS is another chitosan derivative with a wide range of bioactivities, including antimicrobial activity (Liaqat \& Eltem, 2018). COS has been demonstrated to have antimicrobial activity and can be applied with ease due to its high water solubility. Fernandes et al. (2010) documented that low MW $\operatorname{COS}(<3$ and $<5 \mathrm{kDa}$ ) had a greater inhibitory effect against G- bacteria ( $K$. pneumonia, E. coli, and $P$. aeruginosa) than high $\mathrm{MW}$ chitosan (628, 591 and 107 kDa). Lower inhibition efficacy was reported for $\mathrm{G}+$ bacteria (S. epidermidis and S. aureus), which could be owing to the more rigid cell membrane of $\mathrm{G}+$ bacteria. COS with a degree of polymerization (DP) of 4 and DD of $90 \%$, produced from the hydrolysis of chitosan using chitosanase from Pseudomonas CUY8, subdued the proliferation of various microbial strains including $E$. coli ATCC 1150, S. aureus ATCC 6538P, B. subtilis KCTC 1028 and Streptococcus lactis KCTC 1950 as well as several fungi such as Mucor circinelloides ATCC 1216, Saccharomyces cerevisiae ATCC 4126, Penicillium charlesii ATCC 20841, Rhodotorula bacarum ATCC 7025, Aspergillus niger ATCC 1015 and Rhizopus apiculatus ATCC 11996 (Wang et al., 2007). Fernandes et al. (2008) stated that $2.5 \%$ solution of COS with DD in the range of $80-85 \%$, and $\mathrm{MW}$ of $<5$ and $<3 \mathrm{kDa}$, inhibited the growth of Escherichia coli (NCTC 9001) and Staphylococcus aureus (NCTC 8532). COS (MW=8.54 kDa-8.62 kDa) produced by the enzymatic hydrolysis of chitosan (720 kDa, $86.5 \%$
DD) using crude chitinase extracted from Astrosphaeriella sp. BUSK 55-1 had higher antimicrobial activity against $P$. aeruginosa, E. coli, B. subtilis, and $S$. aureus as compared to that manufactured using crude chitinase extracted from Oxydothis sp. BUSK43-2 (Pilantanapak, Waiprib, Eadtem, \& Panbangred, 2017). Table 1 summarizes the antimicrobial activity of chitosan, COS, as well as their derivatives.

\section{Astaxanthin}

Astaxanthin (ASXN) is a class of carotenoids, which is extracted from crustaceans (Mezzomo \& Ferreira, 2016). In crustaceans, ASXN (3,3'-dihydroxy- $\beta, \beta^{\prime}$ carotene-4, $4^{\prime}$-dione) is the major lipophilic carotenoid, which is classified as xanthophyll (Hussein, Sankawa, Goto, Matsumoto, \& Watanabe, 2006). The recovery of ASXN from shrimp (Asghar, Ali, Mozhgan, Parisa, \& Tayebehe, 2016), crawfish (Pu, Bankston, \& Sathivel, 2011) and crab (Coral-Hinostroza \& Bjerkeng, 2002) have been demonstrated.

Different solvents including chloroform, methanol, acetone, hexane etc. have been used to extract ASXN from crustaceans. ASXN ( $0.90 \mathrm{mg} / \mathrm{g}$ oil) was found in oil extracted from the hepatopancreas of the Pacific white shrimp cephalothorax when the mixture of isopropanol and hexane $(1: 1, \mathrm{v} / \mathrm{v})$ was used as the extracting medium (Takeungwongtrakul \& Benjakul, 2016). Hooshmand, Shabanpour, Moosavi-Nasab, and Golmakani (2017) documented the varying amounts of carotenoids from by-products of blue crab (Portunus pelagicus) and shrimp (Penaeus semisulcatus) using hexane, isopropyl alcohol, acetone, the mixture of hexane and acetone $(1: 1 \mathrm{v} / \mathrm{v})$ and the mixture of hexane and isopropyl alcohol $(1: 1 \mathrm{v} / \mathrm{v})$ as the extraction media, in which the highest yields $(6.63$ and $61.32 \mu \mathrm{g} / \mathrm{g}$ for blue crab and shrimp, respectively) was recorded in the extract using acetone. ASXN (72.42 $\mu \mathrm{g} / \mathrm{g})$ was recovered from pink shrimp (Parapenaeus longirostris) shells using acetone as the extracting medium (Sila et al., 2013). GómezEstaca, Calvo, Álvarez-Acero, Montero, and GómezGuillén (2017) documented the extraction of lipid having ASXN content of $7 \mathrm{mg} / \mathrm{g}$ from shrimp waste (Litopenaeus vannamei) using ethyl acetate.

The recovery of ASXN from crustaceans using oil as the extraction medium has been documented. Hooshmand et al. (2017) demonstrated the recovery of carotenoids from by-products of blue crab (Portunus pelagicus) and shrimp (Penaeus semisulcatus) using sesame oil, sunflower oil, soy oil and rice bran oil as the extracting media, in which sunflower oil had the highest yields $(0.21$ and $4.03 \mu \mathrm{g} / \mathrm{g}$ for blue crab and shrimp, respectively). Regardless of the oil used, recovery of carotenoids from shrimp and blue crab by-product was higher when solvent was used (Hooshmand et al., 2017). The yield of ASXN recovered from by-product of shrimp (Farfantepenaeus subtilis) waste, which was previously dried at different temperatures $\left(50-70^{\circ} \mathrm{C}\right)$ before extraction with palm olein, was decreasing with 
Table 1. Antimicrobial properties of chitosan and its derivatives from crustaceans

\begin{tabular}{|c|c|c|c|c|}
\hline $\begin{array}{l}\text { Chitosan/its } \\
\text { derivatives }\end{array}$ & Method of preparation & Target microorganisms & Findings & References \\
\hline \multirow{8}{*}{ 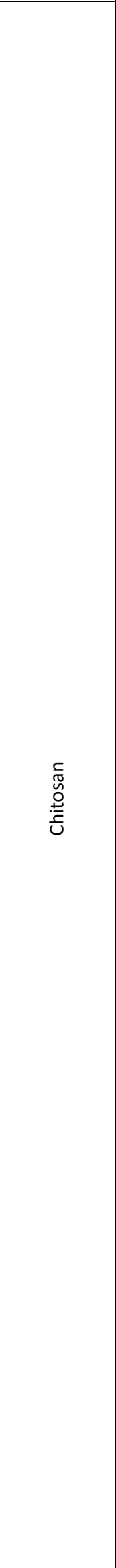 } & $\begin{array}{l}\text { Chitosan prepared from shrimp shell } \\
\text { chitin using } 20 \mathrm{M} \mathrm{NaOH} \text {. Chitosan was } \\
\text { dissolved in } 1.5 \% \text { acetic acid. }\end{array}$ & $\begin{array}{c}\text { Aspergillus niger and Aspergillus } \\
\text { oryzae. }\end{array}$ & $\begin{array}{l}\text { Chitosan had higher } \\
\text { antifungal activity when } \\
\text { compared with the } \\
\text { standard drug of } \\
\text { Fluconazole. }\end{array}$ & $\begin{array}{l}\text { Rajalakshmi, Krithiga, } \\
\text { and Jayachitra (2013) }\end{array}$ \\
\hline & $\begin{array}{l}\text { Chitosan (DD=94.32\%, } \mathrm{MW}=1052.93 \\
\mathrm{~g} / \mathrm{mol} \text { ) produced from shrimp waste } \\
\text { chitin deacetylated with } 60 \% \mathrm{NaOH} \text {. } \\
\text { Chitosan was dissolved in } 1 \mathrm{M} \text { acetic } \\
\text { acid. }\end{array}$ & $\begin{array}{l}\text { Staphylococcus aureus (ATCC 25923), } \\
\text { Candida albicans, and Aspergillus niger. }\end{array}$ & $\begin{array}{l}\text { All bacteria and fungi } \\
\text { tested were inhibited. }\end{array}$ & $\begin{array}{l}\text { Kurniasih and Dewi } \\
\text { (2018) }\end{array}$ \\
\hline & $\begin{array}{l}\text { Commercial chitin and chitosan } \\
\text { dissolved in } 1 \% \text { acetic acid. }\end{array}$ & \begin{tabular}{|} 
Escherichia coli, Klebsiella pneumonia, \\
Pseudomonas aeruginosa, Bacillus \\
subtilis, Methicillin-Resistant \\
Staphylococcus aureus, Staphylococcus \\
aureus, and Micrococcus lutes.
\end{tabular} & $\begin{array}{l}\text { Proliferation of all tested } \\
\text { bacteria was inhibited. } \\
\text { Activity was similar to the } \\
\text { standard drug of } \\
\text { Fluconazole. }\end{array}$ & $\begin{array}{l}\text { Gumgumjee, Shiekh, } \\
\text { and Danial (2018) }\end{array}$ \\
\hline & $\begin{array}{c}\text { Chitosan prepared from chitin } \\
\text { extracted from Podophthalmus vigil } \\
\text { shell waste using } 40 \% \mathrm{NaOH} \text {. Chitosan } \\
\text { was dissolved in } 1 \% \text { acetic acid. }\end{array}$ & $\begin{array}{l}\text { Salmonella typhii, Pseudomonas } \\
\text { auergunosa, Staphylococcus aeureus, } \\
\text { Escherichia coli, Klebsiella pneumonia, } \\
\text { Bacillus substilis. Aspergillus flavus, } \\
\text { Aspergillus fumigatus, Candida } \\
\text { albicans, and Penicillium citrinum. }\end{array}$ & $\begin{array}{l}\text { Antibacterial and antifungal } \\
\text { activities were influenced } \\
\text { by concentration. }\end{array}$ & $\begin{array}{l}\text { Prabu and Natarajan } \\
\text { (2012) }\end{array}$ \\
\hline & $\begin{array}{l}\text { Chitosan prepared from crab (Carcinus } \\
\text { mediterraneus) shell chitin and shrimp } \\
\text { (Penaeus kerathurus) using } 12.5 \mathrm{M} \\
\mathrm{NaOH} \text { having DD of } 78 \text { and, } 88 \%, \\
\text { respectively and MW of } 6120 \text { and } \\
17030 \mathrm{~g} / \mathrm{mol} \text {, respectively. Chitosan } \\
\text { was dissolved in } 0.1 \% \text { acetic acid. }\end{array}$ & \begin{tabular}{|} 
Escherichia coli ATCC 25922, \\
Salmonella typhi ATCC 19430, \\
Klebsiella pneumonia ATCC 13883, \\
Bacillus cereus ATCC 11778, \\
Staphylococcus aureus (ATCC 25923, \\
Enterococcus faecalis ATCC 29212, \\
Micrococcus luteus ATCC 4698, \\
Fusarium solani, Fusarium oxysporum, \\
Aspergillus niger, Alternaria solani, \\
and Botrytis cinerea.
\end{tabular} & $\begin{array}{c}\text { Antimicrobial activity } \\
\text { against all tested organisms } \\
\text { was high. Crab chitosan had } \\
\text { higher antibacterial and } \\
\text { antifungal properties as } \\
\text { compared to shrimp } \\
\text { chitosan. }\end{array}$ & $\begin{array}{c}\text { Hajji, Younes, } \\
\text { Rinaudo, Jellouli, and } \\
\text { Nasri (2015) }\end{array}$ \\
\hline & $\begin{array}{c}\text { Chitosan prepared from chitin } \\
\text { recovered through enzymatic } \\
\text { deproteinization of the Norway lobster } \\
\text { (Nephrops norvegicus) processing by- } \\
\text { products. } \\
\text { Chitosan was dissolved in } 0.1 \% \text { acetic } \\
\text { acid. }\end{array}$ & $\begin{array}{c}\text { Salmonella enterica ATCC 43972, } \\
\text { Escherichia coli ATCC 2592, } \\
\text { Micrococcus luteus ATCC 4698, } \\
\text { Klebsiella pneumoniae ATCC 13883, } \\
\text { Staphylococcus aureus ATCC 25923, } \\
\text { Enterococcus faecalis ATCC 29212, } \\
\text { Bacillus thuringiensis ATCC 10792, } \\
\text { Listeria monocytogenes ATCC 43251, } \\
\text { Salmonella typhinirium ATCC 19430, } \\
\text { Enterobacter sp. Fusarium solani, } \\
\text { Alternaria solani, Botrytis cinerea, and } \\
\text { Aspergillus niger. T. }\end{array}$ & $\begin{array}{l}\text { Antimicrobial activity was } \\
\text { increased with increasing } \\
\text { concentration. }\end{array}$ & Sayari et al. (2016) \\
\hline & $\begin{array}{l}\text { Chitosan-M (C-M) and chitosan-C (C-C) } \\
\text { obtained by enzymatic and alkaline } \\
\text { treatment, having MW of } 19,800 \text { and } \\
5.820 \mathrm{~g} / \mathrm{mol} \text {, respectively. Chitosan was } \\
\text { dissolved in } 0.1 \% \text { acetic acid. }\end{array}$ & $\begin{array}{c}\text { Escherichia coli (ATCC } \\
\text { 25922), Pseudomonas aeruginosa } \\
\text { (ATCC 27853), Klebsiella pneumoniae } \\
\text { (ATCC 13883), Salmonella typhi, } \\
\text { Staphylococcus aureus (ATCC 25923), } \\
\text { Micrococcus luteus (ATCC } \\
\text { 4698), Bacillus cereus (ATCC 11778) } \\
\text { and Enterococcus faecalis (ATCC } \\
\text { 29212). }\end{array}$ & $\begin{array}{c}\text { C-C had a slightly higher } \\
\text { antimicrobial activity than } \\
\text { C-M. }\end{array}$ & Younes et al. (2014) \\
\hline & $\begin{array}{l}\text { Chitosan (DD=80\%) prepared from } \\
\text { Ceriodaphnia quadrangular Ephippia } \\
\text { chitin using } 50 \% \mathrm{NaOH} \text {. Chitosan was } \\
\text { dissolved in } 1 \% \text { acetic acid. }\end{array}$ & \begin{tabular}{|} 
Bacillus subtilis RSKK 244, Listeria \\
monocytogenes \\
ATCC 7644, Lactococcus garvieae, \\
Streptococcus agalactiae Pasteur Inst. \\
55118, Vibrio alginolyticus, Yersinia \\
enterocolitica NCTC 11175 , Salmonella \\
enteritidis RSKK 171, and Candida \\
albicans ATCC 10231.
\end{tabular} & $\begin{array}{l}\text { Chitosan showed high } \\
\text { antimicrobial activities } \\
\text { against the human and } \\
\text { seafood pathogens tested. }\end{array}$ & $\begin{array}{l}\text { Asan-Ozusaglam et } \\
\text { al. (2016) }\end{array}$ \\
\hline
\end{tabular}




\begin{tabular}{|c|c|c|c|c|}
\hline $\begin{array}{l}\text { Chitosan/its } \\
\text { derivatives }\end{array}$ & Method of preparation & Target microorganisms & Findings & References \\
\hline \multirow{5}{*}{ 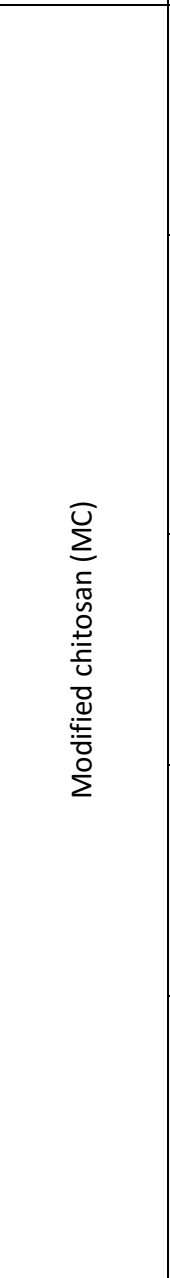 } & $\begin{array}{l}\text { Chitosan dissolved in } 1 \% \text { (v/v) acetic } \\
\text { acid and the chitosan-sugar complex } \\
\text { from six types of sugar (glucose, } \\
\text { fructose, lactose, arabinose, maltose, } \\
\text { and galactose). MC was dissolved in } \\
\text { water. }\end{array}$ & $\begin{array}{c}\text { Escherichia coli (TISTR 780), } \\
\text { Pseudomonas } \\
\text { aeruginosa (TISTR 781), Staphylococcus } \\
\text { aureus } \\
\text { (TISTR 1466) and Bacillus cereus (TISTR } \\
687 \text { ). }\end{array}$ & $\begin{array}{l}\text { Chitosan-sugar complex } \\
\text { had a higher potential to } \\
\text { act as a better } \\
\text { antimicrobial, when } \\
\text { compared to chitosan } \\
\text { alone. }\end{array}$ & $\begin{array}{l}\text { Mahae, Chalat, and } \\
\text { Muhamud (2011) }\end{array}$ \\
\hline & $\begin{array}{c}\text { Chitosan (DD=67.58- } 95.19 \%, \mathrm{MW}= \\
949.95-4467.05 \mathrm{kDa}) \text { from shrimp chitin } \\
\text { at three particle sizes ( } 20,40 \text { and } 60 \\
\text { mesh) by deacetylating with different } \\
\text { concentrations of } \mathrm{NaOH} \text { solution ( } 30 \% \text {, } \\
40 \% \text { and } 50 \% \text { ) under microwave } \\
\text { irradiation for } 10 \text { min. MC was } \\
\text { dissolved in } 1 \% \text { acetic acid. }\end{array}$ & $\begin{array}{l}\text { Salmonella typhimurium ATCC } 14028 \\
\text { and Escherichia coli ATCC } 25922 .\end{array}$ & $\begin{array}{l}\text { Inhibitory effects differed, } \\
\text { depending on the types of } \\
\text { chitosan and the tested } \\
\text { bacteria with greater } \\
\text { antimicrobial activity } \\
\text { against Salmonella } \\
\text { typhimurium than } \\
\text { Escherichia coli. }\end{array}$ & $\begin{array}{l}\text { Mahdy Samar, El- } \\
\text { Kalyoubi, Khalaf, and } \\
\text { Abd El-Razik (2013) }\end{array}$ \\
\hline & $\begin{array}{c}\text { Chitosan/hydroxypropyl } \\
\text { methylcellulose film-forming hydrosols } \\
\text { hydrolyzed from low MW chitosan } \\
(\mathrm{DD}=75 \%-85 \%) \text { with cellulase at two } \\
\text { concentrations ( } 0.05 \% \text { and } 0.1 \%) . \mathrm{MC} \\
\text { was dissolved in water. }\end{array}$ & $\begin{array}{c}\text { Pseudomonas fluorescens PCM2123, } \\
\text { Yersinia enterocolitica PCM1889, } \\
\text { Bacillus cereus PCM2003, } \\
\text { Staphylococcus aureus PCM1932. }\end{array}$ & $\begin{array}{c}\text { Antibacterial activities were } \\
\text { dependent on cellulase } \\
\text { addition and hydrolysis } \\
\text { time of polysaccharide } \\
\text { solution. }\end{array}$ & $\begin{array}{c}\text { Zimoch-Korzycka, } \\
\text { Bobak, and Jarmoluk } \\
(2016)\end{array}$ \\
\hline & $\begin{array}{l}\text { Chitosan with classical deacetylation } \\
\text { (CDC) and ultrasound-assisted } \\
\text { deacetylated chitosan (UDC) with DD of } \\
73.68 \% \text { and } 83.55 \% \text {, respectively. All } \\
\text { chitosans samples were dissolved in } 1 \% \\
\text { acetic acid. }\end{array}$ & $\begin{array}{c}\text { Staphylococcus aureus } \\
\text { ATCC, Escherichia coli ATCC, } \\
\text { Pseudomonas aeruginosa ATCC, } \\
\text { Klebsiella pneumonia ATCC, Candida } \\
\text { albicans ATCC, Candida parapsilosis } \\
\text { ATCC. }\end{array}$ & $\begin{array}{l}\text { Antimicrobial activities } \\
\text { were increased with } \\
\text { augmenting the degree of } \\
\text { deacetylation. UDC } \\
\text { exhibited higher activity as } \\
\text { compared to CDC. }\end{array}$ & Hafsa et al. (2016) \\
\hline & $\begin{array}{l}\text { Chitosan (MW=1000 } \mathrm{kDa}, \mathrm{DD}=80.23 \%) \\
\text { obtained by } 50 \% \mathrm{NaOH} \text { treatment of } \\
\text { chitin without and with modification by } \\
\text { ultraviolet or ozone (UV/ozone) at } \\
\text { different times. All chitosan were } \\
\text { dissolved in } 1 \% \text { acetic acid. }\end{array}$ & $\begin{array}{c}\text { Staphylococcus aureus ATCC 29213, } \\
\text { Bacillus } \\
\text { cereus, Bacillus subtilis ATCC6633, } \\
\text { Escherichia coli ATCC 25922, } \\
\text { Pseudomonas aeruginosa ATCC27953, } \\
\text { Aspergillus Niger, Candida albicans } \\
\text { NRRL Y-4773, Candida tropicalis and } \\
\text { Rhizopus. }\end{array}$ & $\begin{array}{l}\text { No differences in the } \\
\text { antibacterial properties of } \\
\text { unmodified and modified } \\
\text { chitosan were attained. }\end{array}$ & Ragab et al. (2018) \\
\hline \multirow{4}{*}{ 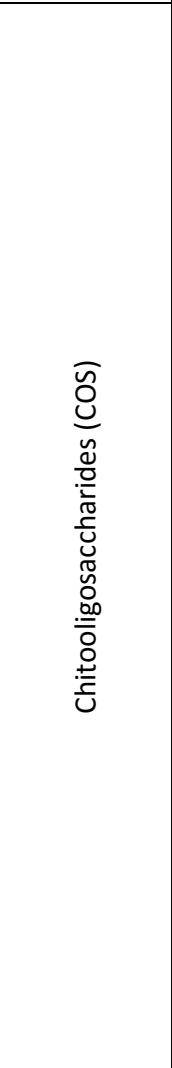 } & $\begin{array}{l}\text { Chitin extracted from shrimp sell waste } \\
\text { with } \mathrm{MW} \text { of } 338 \mathrm{kDa} \text { and } \mathrm{DD} \text { of } 35 \% \text { ), } \\
\text { chitosan ( } \mathrm{DD}=80 \% \mathrm{Mw}=12 \mathrm{kDa} \text { ) } \\
\text { prepared from chitin using } 50 \% \mathrm{NaOH} \text {, } \\
\mathrm{N} \text {-acetyl chitooligosaccharides (chitin } \\
\text { hydrolyzed with } \mathrm{HCl} \text { ) and } \\
\text { chitooligosaccharides (chitosan } \\
\text { hydrolyzed with } \mathrm{HCl} \text { ). Chitin, chitosan, } \\
\text { and chitooligosaccharides were } \\
\text { dissolved in cultured bacteria } \\
\text { suspension }\end{array}$ & $\begin{array}{c}\text { Staphylococcus aureus ATCC 25923, S. } \\
\text { aureus ATCC 43300, Bacillus subtilis, } \\
\text { Bacillus cereus, Escherichia coli ATCC } \\
\text { 25922, Pseudomonas aeruginosa ATCC } \\
\text { 27853, Salmonella typhimurium, Vibrio } \\
\text { cholerae, Shigella dysenteriae, } \\
\text { Prevotella melaninogenica and } \\
\text { Bacteroides fragilis. }\end{array}$ & $\begin{array}{c}\text { Chitin exhibited a } \\
\text { bacteriostatic effect on } E \text {. } \\
\text { coli, Vibrio cholerae, } \\
\text { Shigella dysenteriae, and } \\
\text { Bacteroides fragilis. } \\
\text { Chitosan exhibited a } \\
\text { bacteriostatic effect on all } \\
\text { bacteria tested, except } \\
\text { Salmonella typhimurium. } \\
\text { Chitosan oligomers } \\
\text { exhibited a bactericidal } \\
\text { effect on all bacteria tested. }\end{array}$ & $\begin{array}{l}\text { Benhabiles et al. } \\
\text { (2012) }\end{array}$ \\
\hline & $\begin{array}{l}\text { Chitosan oligomers produced by } \\
\text { hydrolysis of chitosan with nitrous acid } \\
\left(\mathrm{NaNO}_{2}+\mathrm{CH}_{3} \mathrm{COOH}\right) \text {. Chitosan was } \\
\text { prepared from shrimp shell waste using } \\
50 \% \mathrm{NaOH} \text {. COS was dissolved in } 1 \% \\
\text { acetic acid }\end{array}$ & $\begin{array}{l}\text { Enterobacter aerogen NCDC 106, } \\
\text { Enterococcus faecalis NCDC 119, } \\
\text { Escherichia coli NCDC 134, and } \\
\text { Staphylococcus aureus NCDC } 109\end{array}$ & $\begin{array}{c}\text { Tested microorganisms } \\
\text { were inhibited but higher } \\
\text { inhibition against } \\
\text { Enterococcus faecalis was } \\
\text { noticeable. }\end{array}$ & Varun et al. (2017) \\
\hline & $\begin{array}{l}\text { Chitooligosaccharides with different } \\
\text { Mw prepared }>100 \mathrm{kDa}, 100 \text { to } 10 \mathrm{kDa} \text {, } \\
10 \text { to } 1 \mathrm{kDa} \text { and }<1 \mathrm{kDa} \text { by enzymatic } \\
\text { hydrolysis of chitosan (MW= } 300 \mathrm{KDa} \text { ) } \\
\text { using immobilized pepper chitosanase. }\end{array}$ & $\begin{array}{l}\text { Bacillus cereus, Bacillus subtilis, } \\
\text { Staphylococcus aureus, Escherichia coli, } \\
\text { Pseudomonas aeruginosa, Candida } \\
\text { albicans, Saccharomyces chevalieri, } \\
\text { Macrophomina phaseolina, and } \\
\text { Aspergillus niger }\end{array}$ & $\begin{array}{c}\text { Antimicrobial activities } \\
\text { depended on the type of } \\
\text { the microorganism and not } \\
\text { on MW. }\end{array}$ & $\begin{array}{c}\text { El-Sayed, Omar, El- } \\
\text { Sayed, and Shousha } \\
(2017)\end{array}$ \\
\hline & $\begin{array}{l}\text { Chitooligosaccharides (MW= } 5.1,14.3 \text {, } \\
\text { and } 41.1 \mathrm{k} \mathrm{Da} \text { ) prepared from } \\
\text { commercial chitosans with } 80 \% \text { and } \\
90 \% \text { DD using papain. COS was } \\
\text { dissolved in } 0.25 \% \text { acetic acid solution }\end{array}$ & $\begin{array}{l}\text { Escherichia coli, Staphylococcus aureus, } \\
\text { Salmonella enterica serovar } \\
\text { Typhimurium and Salmonella enterica } \\
\text { serovar Enteritidis }\end{array}$ & $\begin{array}{c}\text { All chitooligosaccharides } \\
\text { inhibited the tested } \\
\text { microorganisms, however } \\
\text { higher activity was reported } \\
\text { for Escherichia coli. }\end{array}$ & $\begin{array}{l}\text { Laokuldilok et al. } \\
\qquad(2017)\end{array}$ \\
\hline
\end{tabular}


augmenting drying temperatures. These was attributed to the isomerization of ASXN to the cis form caused by light, oxidation as well as high temperature (Silva, Rodrigues, Silva, \& Rodrigues, 2018). Flaxseed oil was used as the extracting medium for the recovery of ASXN in the by-product of crawfish (Procambarus clarkii). The recovered ASXN was then microencapsulated in sodium caseinate by spray drying method. ASXN content of $13.76 \mathrm{mg} / \mathrm{g}$ powder was recorded in the microencapsulated ASX powder (Pu et al., 2011).

Carotenoids, especially ASXN has also been extracted from crustaceans using enzymes hydrolysis, in which carotenoids are released during the hydrolysis or breakdown of carotenoprotein complex (Olatunde \& Benjakul, 2020). Papain trypsin and alcalase combined with sunflower oil was used for the extraction of carotenoids from Penaeus indicus processing byproduct. Higher content of carotenoids (24.4-28.6 $\mu \mathrm{g} / \mathrm{g}$ sample) was recorded for the extraction with enzymes in comparison with the control $(23.7 \mu \mathrm{g} / \mathrm{g}$ sample) (Sachindra \& Mahendrakar, 2011). Senphan, Benjakul, and Kishimura (2014) found an augmenting carotenoprotein content from shrimp shell with increasing enzymes concentration as well as hydrolysis time when proteases from hepatopancreas of Pacific white shrimp was used. Trypsin from tuna spleen showed promising potential for extracting carotenoprotein from Pacific white shrimp (Poonsin et al., 2018). Sowmya, Rathinaraj, and Sachindra (2011) demonstrated the recovery of carotenoprotein for shrimp (Penaeus monodon) heads using protease isolated from the same species.

\section{Antimicrobial Properties}

ASXN extracted from prawn (Penaeus monodon) using high-pressure processing (238 MPa for $16.29 \mathrm{~min}$ ) with a mixture of methanol and acetone $(3: 7 \mathrm{v} / \mathrm{v})$ possessed better antibacterial properties against $B$. subtilis, S. aureus, and Ent. aerogenes E. coli when compared to ASXN extracted with the solvent only (Irna, Jaswir, Othman, \& Jimat, 2017). Suganya and Asheeba (2015) reported that $E$. coli isolated from spoiled milk and rotten meat was inhibited by ASXN extracted from three spotted, spiny king and blue crab using a dimethyl sulfoxide and acetone solvent $(1: 3, \mathrm{v} / \mathrm{v})$ mixture as extracting medium. Although the antimicrobial activities of carotenoids, especially ASXN, from crustaceans, are very promising, there is limited information on in vitro antimicrobial properties or mode of action of ASXN for microbial inhibition.

\section{Applications of Antimicrobial Compounds from Crustaceans in Extending the Shelf-Life of MBFs}

Among all the antimicrobial compounds from crustaceans, chitosan and its derivatives have been widely used for assuring the safety of MBFs as well as shelf-life extension. Chitosan is mainly used as a coating solution for MFBs. Chitosan ( $1 \% \mathrm{w} / \mathrm{v})$ dissolved in lactic acid $(1 \% \mathrm{v} / \mathrm{v})$ acid and glycerol $(0.1 \% \mathrm{v} / \mathrm{v})$ used as coating for liquid smoked Nile tilapia (Oreochromis niloticus) fillet significantly reduced both psychrotrophic and mesophilic bacteria counts, in which the shelf-life of 30 days was found in comparison with 10 days recorded for the control (without coating) during the storage at 4 o $C$ (da Silva Santos et al., 2017). Silver carp slices treated with chitosan $(2 \% \mathrm{w} / \mathrm{v})$ dissolved in glacial acetic acid, retained its good quality characteristics with low oxidation as well as low microbial load in comparison with the untreated counterpart during frozen storage $\left(-3{ }^{\circ} \mathrm{C}\right)$ for 30 days (Fan et al., 2009). Chamanara, Shabanpour, Khomeiri, and Gorgin (2013) reported a lower total psychrotrophic count for butterfly-shaped rainbow trout (Oncorhynchus mykiss) coated with $2 \%$ chitosan $(\mathrm{w} / \mathrm{v})$ prepared in $1 \%$ acetic acid as compared to the untreated counterpart throughout refrigerated storage at 4 으 for 15 days. Increases in TVC, Vibrio parahaemolyticus, $V$. cholerae, $V$. alginolyticus and total coliform counts in tilapia (Oreochromis niloticus) fillets were lower for those treated with $2 \%$ shrimp chitosan (prepared in $1 \%$ acetic acid) in comparison with the control during iced storage for 21 days (ChaparroHernández et al., 2015). Atlantic salmon (Salmo salar) coated with chitosan extracted from lobsters $(1 \% \mathrm{w} / \mathrm{v}$ dissolved in $1 \% \mathrm{v} / \mathrm{v}$ lactic acid) had lower bacterial load as compared to the untreated counterpart during storage at 0 ㅇ C for 18 days (Souza et al., 2010).

To increase the efficacy of antimicrobial compounds from crustaceans, several compounds, particularly polyphenols have been incorporated in combination. Li, Li, Hu, and $\mathrm{Li}$ (2013) documented a shelf-life of 20 days for red drum (Sciaenops ocellatus) fillets coated with chitosan $(1.5 \% \mathrm{w} / \mathrm{v})$ dissolved in acetic acid $(1 \% \mathrm{v} / \mathrm{v})$ combined with either tea polyphenols $(0.2 \% \mathrm{w} / \mathrm{v})$ or grape seed extract $(0.2 \% \mathrm{w} / \mathrm{v})$ as compared to the 12 days reported for the control (without coating). Large yellow croaker (Pseudosciaena crocea) coated with chitosan $(1.5 \% \mathrm{w} / \mathrm{v})$ in acetic acid $(1 \% \mathrm{v} / \mathrm{v})$ combined with either tea polyphenol $(0.2 \%$ $\mathrm{w} / \mathrm{v})$ or rosemary extract $(0.2 \% \mathrm{w} / \mathrm{v})$ had a shelf-life of 20 days as compared to the control (12 days) during storage at 4 으 (Li et al., 2012). Ramírez-Guerra et al. (2018) reported that the shelf-life of Sierra (Scomberomorus sierra) fillets packaged in edible chitosan film (prepared by dissolving $1 \% \mathrm{w} / \mathrm{v}$ chitosan in $1 \% \mathrm{v} / \mathrm{v}$ acetic acid and $0.5 \% \mathrm{v} / \mathrm{v}$ glycerol) incorporated with $0.3 \%(\mathrm{v} / \mathrm{v})$ ethanolic tomato plant extract was extended by at least 5 days when compared to the control. Overall, the rate of change in the total viable count (TVC) was lower in fillets coated with chitosan incorporated with tea polyphenols, followed by fillet coated with chitosan only and tea polyphenol only, lastly in the control (Ramírez-Guerra et al., 2018). Indian salmon fillets coated with 1) $1.5 \%$ chitosan $+30 \%$ lime juice, $+10 \%$ gelatin, 2) $1.5 \%$ chitosan $+30 \%$ garlic extract $+10 \%$ gelatin, and 3 ) $10 \%$ gelatin solution had shelf-life of 16,16 , and 8 days, respectively, compared to 4 days 
Table 2. Recent applications of chitosan and chitosan in combination with other preservatives in retarding microbial proliferation in MBFs during refrigerated storage

\begin{tabular}{|c|c|c|c|}
\hline Chitosan and its derivatives & Marine based foods & Findings & References \\
\hline Chitosan $(0-2.0 \% \mathrm{w} / \mathrm{w})$ & $\begin{array}{l}\text { Surimi gel made from } \\
\text { African catfish (Clarias } \\
\text { gariepinus) }\end{array}$ & $\begin{array}{l}\text { The addition of } 1.5-2.0 \%(\mathrm{w} / \mathrm{w}) \text { chitosan } \\
\text { inhibited the proliferation of bacteria in catfish } \\
\text { surimi gels during the refrigerated storage at } 4 \\
\text { of for } 20 \text { days }\end{array}$ & $\begin{array}{l}\text { Amiza and Kang } \\
\text { (2013) }\end{array}$ \\
\hline $\begin{array}{l}\text { Chitosan solution }(5.0 \mathrm{~g} / \mathrm{l}) \\
\text { prepared in } 1 \% \text { acetic acid. }\end{array}$ & $\begin{array}{l}\text { Aquacultured tilapia } \\
\text { (Oreochromis niloticus) }\end{array}$ & $\begin{array}{l}\text { A shelf-life of } 6 \text { days was observed for untreated } \\
\text { tilapia fillets, while a shelf-life of } 12 \text { days was } \\
\text { observed for chitosan-treated samples }\end{array}$ & $\begin{array}{l}\text { Cao, Liu, Yin, and } \\
\text { Wu (2012) }\end{array}$ \\
\hline $\begin{array}{l}\text { Chitosan coating solution ( } 1 \\
\text { and } 2 \% \mathrm{w} / \mathrm{v} \text { in } 1 \% \text { acetic acid) }\end{array}$ & $\begin{array}{l}\text { Indian oil sardine } \\
\text { (Sardinella longiceps) } \\
\text { fillets }\end{array}$ & $\begin{array}{l}\text { The shelf-life of fillets treated with } 1 \text { and } 2 \% \\
\text { chitosan was extended to } 7 \text { and } 9 \text { days, } \\
\text { respectively during storage at } 4 \text { o- as compared } \\
\text { to the control ( } 5 \text { days). }\end{array}$ & $\begin{array}{l}\text { Mohan, } \\
\text { Ravishankar, } \\
\text { Lalitha, and } \\
\text { Srinivasa Gopal } \\
\text { (2012) } \\
\end{array}$ \\
\hline $\begin{array}{l}\text { Chitosan coating solution ( } 2 \% \\
w / v \text { in } 1 \% \text { acetic acid) }\end{array}$ & $\begin{array}{c}\text { Rainbow trout } \\
\text { (Oncorhynchus mykiss) }\end{array}$ & $\begin{array}{l}\text { Total mesophilic and psychrophylic counts were } \\
\text { lower in hot smoked vaccum packed fillets } \\
\text { treated with chitosan as compared to the } \\
\text { control group during refrigerated storage at } 4 \\
{ }^{\circ} \mathrm{C} \text { for } 24 \text { days }\end{array}$ & $\begin{array}{l}\text { Yağin and } \\
\text { Büyükyörük } \\
(2017)\end{array}$ \\
\hline $\begin{array}{l}\text { Chitosan coating solution } \\
\text { prepared with } 2 \%(\mathrm{w} / \mathrm{v}) \\
\text { chitosan in } 1 \% \mathrm{v} / \mathrm{v} \text { acetic acid } \\
\text { incorporated with } 0.2 \%(\mathrm{w} / \mathrm{v}) \\
\text { black pepper essential oil } 1.5 \% \\
(\mathrm{v} / \mathrm{v})\end{array}$ & $\begin{array}{c}\text { Common carp (Cyprinus } \\
\text { carpio) }\end{array}$ & $\begin{array}{c}\text { Changes in aerobic plate count, psychrophilic } \\
\text { bacteria count, lactic acid bacteria, and } \\
\text { Enterobacteriaceae bacteria counts were } \\
\text { lowered in crap treated with chitosan and black } \\
\text { pepper essential oil as compared to that treated } \\
\text { with chitosan only and the control. }\end{array}$ & $\begin{array}{l}\text { Moosavi-Nasab } \\
\text { et al. (2016) }\end{array}$ \\
\hline $\begin{array}{l}\text { Chitosan coating solution } \\
\text { prepared with } 1 \%(\mathrm{w} / \mathrm{v}) \\
\text { chitosan in } 1 \% \mathrm{v} / \mathrm{v} \text { acetic acid } \\
\text { and } 0.2 \%(\mathrm{w} / \mathrm{v}) \text { antioxidant of } \\
\text { bamboo leaves. }\end{array}$ & $\begin{array}{l}\text { Silver carp } \\
\text { (Hypophthalmicthys } \\
\text { molitrix) }\end{array}$ & $\begin{array}{l}\text { TVC was lower in treated samples throughout } \\
\text { refrigerated storage at } 4 \stackrel{\circ}{ } \mathrm{C} \text { for } 24 \text { days as } \\
\text { compared to the untreated counterpart. }\end{array}$ & $\begin{array}{l}\text { Wenjiao, } \\
\text { Yongkui, Pan, and } \\
\text { Yuwen (2013) }\end{array}$ \\
\hline $\begin{array}{l}\text { Chitosan coating solution } \\
\text { prepared with } 2 \%(\mathrm{w} / \mathrm{v}) \\
\text { chitosan in } 1 \% \mathrm{v} / \mathrm{v} \text { acetic acid } \\
\text { combined with } 1.5 \% \text { cinnamon } \\
\text { essential oil }\end{array}$ & $\begin{array}{l}\text { Rainbow trouts } \\
\text { (Oncorhynchus mykiss) } \\
\text { fillets }\end{array}$ & $\begin{array}{l}\text { The shelf-life of fillets treated with chitosan only } \\
\text { and those treated with chitosan and essential oil } \\
\text { was extended by twice that of the control } \\
\text { during refrigerated storage at } 4 \text { o } C \text { for } 16 \text { days. }\end{array}$ & $\begin{array}{l}\text { Ojagh, Rezaei, } \\
\text { Razavi, and } \\
\text { Hosseini (2010) }\end{array}$ \\
\hline $\begin{array}{l}\text { Chitosan-based edible coatings } \\
\text { prepared by dissolving } 3 \% \\
\text { chitosan in water incorporated } \\
\text { with garlic oil at } 0.5,1.0 \text { and } \\
1.5 \%\end{array}$ & $\begin{array}{l}\text { Deepwater pink shrimps } \\
\text { (Parapenaeus } \\
\text { longirostris) }\end{array}$ & $\begin{array}{l}\text { Coating treatment, treatment, and the } \\
\text { combined effect of treatment and period } \\
\text { influenced the antibacterial efficacy of chitosan. } \\
\text { The shelf of shrimp treated with chitosan was } \\
\text { extended by } 3 \text { days at } 4 \text { o } C \text { storage. }\end{array}$ & $\begin{array}{c}\text { Aşik and } \\
\text { Candoğan (2014) }\end{array}$ \\
\hline $\begin{array}{l}\text { Chitosan }(2 \% \mathrm{w} / \mathrm{v}) \text { prepared in } \\
1 \% \text { acetic acid incorporated } \\
\text { with Thymus vulgaris essential } \\
\text { oil }(1 \% \mathrm{w} / \mathrm{v}) \text {. }\end{array}$ & $\begin{array}{c}\text { Butterfly-shaped } \\
\text { rainbow trout } \\
\text { (Oncorhynchus mykiss) }\end{array}$ & $\begin{array}{l}\text { The lower total psychrotrophic count was } \\
\text { observed as compared to that treated with } \\
\text { chitosan only and the control. The shelf-life was } \\
\text { extended to more than } 15 \text { days during } \\
\text { refrigerated storage at } 4 \text { o } \mathrm{C} \text {. }\end{array}$ & $\begin{array}{c}\text { Chamanara et al. } \\
\text { (2013) }\end{array}$ \\
\hline $\begin{array}{l}\text { Chitosan }(2 \% \mathrm{w} / \mathrm{v}) \text { recovered } \\
\text { from shrimp prepared in } 1 \% \\
\text { acetic acid incorporated with } \\
\text { carvacrol at different } \\
\text { concentrations }(0.125 \text { and } \\
0.25 \% \mathrm{w} / \mathrm{v}) .\end{array}$ & $\begin{array}{c}\text { Tilapia (Oreochromis } \\
\text { niloticus) }\end{array}$ & $\begin{array}{c}\text { Lower increases in total viable, Vibrio } \\
\text { parahaemolyticus, } V \text {. cholerae, } V \text {. alginolyticus } \\
\text { and total coliform counts in fillets were } \\
\text { observed during ice storage of } 21 \text { days. Efficacy } \\
\text { was increased with augmenting concentrations } \\
\text { of carvacrol in chitosan solution. }\end{array}$ & $\begin{array}{c}\text { Chaparro- } \\
\text { Hernández et al. } \\
\text { (2015) }\end{array}$ \\
\hline
\end{tabular}

recorded for the control (without any treatment) (Thaker, Hanjabam, Gudipati, \& Kannuchamy, 2017). Indian mackerel (Rastrelliger kanagurta) wrapped in chitosan film (prepared by dissolving $1.5 \% \mathrm{w} / \mathrm{v}$ chitosan in $1 \% \mathrm{v} / \mathrm{v}$ acetic acid) incorporated with $5 \% \mathrm{v} / \mathrm{v}$ Garcinia atroviridis had lower increases in $\mathrm{pH}$ and TVC as compared with the fillets wrapped only with chitosan throughout refrigerated storage at $4^{\circ} \mathrm{C}$ for 6 days (Zaman, Lin, \& Phing, 2018).

Aşik and Candoğan (2014) reported that shrimps coated with $1 \%$ chitosan $(\mathrm{w} / \mathrm{v})$ dissolved in $1 \%$ acetic acid in conjunction with garlic oil (1.5\%) had a shelf-life of 15 days as compared to 5 days found for the control. Lower microbial loads were noted in deep-water pink 
shrimp wrapped with chitosan film prepared by dissolving $1.5 \%$ chitosan $(\mathrm{w} / \mathrm{v})$ in combination with orange peel essential oil (0.5-2.0\%) as compared to that wrapped with films prepared by $1.5 \%$ chitosan only and the unwrapped counterpart during refrigerated storage at 4 으 (Alparslan \& Baygar, 2017). Aşik and Candoğan (2014) reported the reduced microbial proliferation in shrimps coated with $3 \%$ chitosan $(w / v)$ combined with garlic oil (up to $1.5 \%$ ), which prolonged the shelf-life by 5 days.

Antimicrobial compounds from crustaceans, particularly chitosan and its derivatives, have been included in the formulation of several products, for retarding the microbial proliferation during storage. For example, the shelf-life of restructured fish products from pangasius (Pangasianodon hypophthalmus) surimi incorporated with $0.75 \%$ chitosan was extended to 17 days as compared to that without chitosan (10 days) during refrigerated storage at $4 \circ \mathrm{O} C$ (Jeyakumari et al., 2016). Recent applications of chitosan and derivatives, alone and in combination with other preservatives for retarding microbial proliferation in MBFs are presented in Table 2.

\section{Conclusion and Future Prospectus}

Antimicrobial compounds can be extracted from crustaceans, which could serve as natural preservative in many food and food products. The recovery of these antimicrobials from the by-product during the processing of crustaceans could lead to value addition, since this discard contains significant quantities of carbohydrates, pigments and structurally diverse proteins, that could serve as substrates for the generation of novel antimicrobials or act an antimicrobial themselves. Antimicrobial peptides, carotenoids as well as chitosan and its derivatives showed promising potential as a natural antimicrobial compound, which is been increasingly preferred over antibiotics because of being nontoxic and posing no health concerns. These aforementioned compounds have also been successfully produced and applied in different MBFs. However, their application in MBF is not fully exploited. Therefore, future research must be directed toward the application of antimicrobials from crustaceans, particularly peptides, carotenoids or COS directly or along with the coating, or other technologies for extending the shelf-life of MBFs. Also, screening and identification of novel antimicrobials from crustaceans processing by-products should be researched extensively.

\section{Acknowledgments}

This research was supported by the Higher Education Research Promotion Office, Thailand's Education Hub for the Southern Region of ASEAN Countries Project Office of the Higher Education Commission, and the Graduate School of Prince of
Songkla University. Prince of Songkla University (Grant No. AGR6302013N) was acknowledged for financial support.

\section{References}

Abdollahzadeh, E., Rezaei, M., \& Hosseini, H. (2014). Antibacterial activity of plant essential oils and extracts: The role of thyme essential oil, nisin, and their combination to control Listeria monocytogenes inoculated in minced fish meat. Food Control, 35(1), 177 183.

Al Bulushi, I. M., Poole, S. E., Barlow, R., Deeth, H. C., \& Dykes, G. A. (2010). Speciation of Gram-positive bacteria in fresh and ambient-stored sub-tropical marine fish. International Journal of Food Microbiology, 138(1), 3238.

Alparslan, Y., \& Baygar, T. (2017). Effect of chitosan film coating combined with orange peel essential oil on the shelf life of deep water pink shrimp. Food and Bioprocess Technology, 10(5), 842-853.

Amiza, M., \& Kang, W. (2013). Effect of chitosan on gelling properties, lipid oxidation, and microbial load of surimi gel made from African catfish (Clarias gariepinus). International Food Research Journal, 20(4), 1585.

Anderson, J. L., Valderrama, D., \& Jory, D. (2013). Shrimp production review. Global Outlook Aquaculture Leadership-GOAL, 43.

Arcidiacono, S., \& Kaplan, D. (1992). Molecular weight distribution of chitosan isolated from Mucor rouxii under different culture and processing conditions. Biotechnology and Bioengineering, 39(3), 281-286.

Asan-Ozusaglam, M., Cakmak, Y. S., Kaya, M., Erdogan, S., Baran, T., Mentes, A., \& Saman, I. (2016). Antimicrobial and antioxidant properties of Ceriodaphnia quadrangula Ephippia chitosan. Romanian Biotechnological Letters, 21(5), 11881.

Asghar, A., Ali, S., Mozhgan, G., Parisa, S., \& Tayebehe, A. S. (2016). The comparison survey antioxidant power and content of extracted astaxanthin from shrimp waste with acid, alkaline and enzymatic methods. African Journal of Basic and Applied Sciences, 8(6), 321-323.

Aşik, E., \& Candoğan, K. (2014). Effects of chitosan coatings incorporated with garlic oil on quality characteristics of shrimp. Journal of Food Quality, 37(4), 237-246.

Bahar, A. A., \& Ren, D. (2013). Antimicrobial peptides. Pharmaceuticals (Basel, Switzerland), 6(12), 1543-1575.

Batista, A., Dantas, G., Santos, J., \& Amorim, R. (2011). Antimicrobial effects of native chitosan against opportunistic Gram-negative bacteria. Microbiology Journal, 1, 105-112.

Bekaert, K., Devriese, L., Maes, S., \& Robbens, J. (2015). Characterization of the dominant bacterial communities during storage of Norway lobster and Norway lobster tails (Nephrops norvegicus) based on $16 \mathrm{~S}$ rDNA analysis by PCR-DGGE. Food Microbiology, 46, 132-138.

Benhabiles, M. S., Salah, R., Lounici, H., Drouiche, N., Goosen, M. F. A., \& Mameri, N. (2012). Antibacterial activity of chitin, chitosan and its oligomers prepared from shrimp shell waste. Food Hydrocolloids, 29(1), 48-56.

Bradshaw, J. P. (2003). Cationic antimicrobial peptides. BioDrugs, 17(4), 233-240.

Brown, K. L., \& Hancock, R. E. (2006). Cationic host defense (antimicrobial) peptides. Current Opinion in Immunology, 18(1), 24-30. 
Cao, R., Liu, Q., Yin, B., \& Wu, B. (2012). Chitosan extends the shelf-life of filleted tilapia (Oreochromis niloticus) during refrigerated storage. Journal of Ocean University of China, 11(3), 408-412.

Chamanara, V., Shabanpour, B., Khomeiri, M., \& Gorgin, S. (2013). Shelf-life extension of fish samples by using enriched chitosan coating with thyme essential oil. Journal of Aquatic Food Product Technology, 22(1), 3-10.

Chaparro-Hernández, S., Ruíz-Cruz, S., Márquez-Ríos, E., Ocaño-Higuera, V. M., Valenzuela-López, C. C., ORNELAS-PAZ, J. d. J., \& Del-Toro-Sánchez, C. L. (2015). Effect of chitosan-carvacrol edible coatings on the quality and shelf life of tilapia (Oreochromis niloticus) fillets stored in ice. Food Science and Technology, 35(4), 734-741.

Chen, B., Fan, D.-Q., Zhu, K.-X., Shan, Z.-G., Chen, F.-Y., Hou, L., Cai, L., \& Wang, K.-J. (2015). Mechanism study on a new antimicrobial peptide Sphistin derived from the $\mathrm{N}$ terminus of crab histone $\mathrm{H} 2 \mathrm{~A}$ identified in haemolymphs of Scylla paramamosain. Fish and Shellfish Immunology, 47(2), 833-846.

Chen, Y., Li, J., Li, Q., Shen, Y., Ge, Z., Zhang, W., \& Chen, S. (2016). Enhanced water-solubility, antibacterial activity and biocompatibility upon introducing sulfobetaine and quaternary ammonium to chitosan. Carbohydrate Polymers, 143, 246-253.

Coral-Hinostroza, G. N., \& Bjerkeng, B. (2002). Astaxanthin from the red crab langostilla (Pleuroncodes planipes): optical R/S isomers and fatty acid moieties of astaxanthin esters. Comparative Biochemistry and Physiology Part B: Biochemistry and Molecular Biology, 133(3), 437-444.

da Silva Santos, F. M., da Silva, A. I. M., Vieira, C. B., de Araújo, M. H., da Silva, A. L. C., Carneiro-da-Cunha, M. d. G., de Souza, B. W. S., \& de Souza Bezerra, R. (2017). Use of chitosan coating in increasing the shelf life of liquid smoked Nile tilapia (Oreochromis niloticus) fillet. Journal of Food Science and Technology, 54(5), 1304-1311.

Dalgaard, P. (2000). Fresh and lightly preserved seafood. In C. M. D. Man \& A. A. Jones (Eds.), Shelf-life evaluation of food (pp. 110-139). London: Aspen Publisher Inc.

Djellouli, M., López-Caballero, M. E., Arancibia, M. Y., Karam, N., \& Martínez-Alvarez, O. (2019). Antioxidant and antimicrobial enhancement by reaction of protein hydrolysates derived from shrimp by-products with glucosamine. Waste and Biomass Valorization, 1-15.

Dutta, P. K., Dutta, J., \& Tripathi, V. (2004). Chitin and chitosan: Chemistry, properties and applications. Journal of Scientific and Industrial Research, 63, 20-31.

El-Sayed, S. T., Omar, N. I., El-Sayed, E.-S. M., \& Shousha, W. G. (2017). Evaluation Antioxidant and cytotoxic activities of novel chitooligosaccharides prepared from chitosan via enzymatic hydrolysis and ultrafiltration. Journal of Applied Pharmaceutical Science, 7(11), 050-055.

Elieh-Ali-Komi, D., \& Hamblin, M. R. (2016). Chitin and chitosan: production and application of versatile biomedical nanomaterials. International Journal of Advanced Research, 4(3), 411.

Ennaas, N., Hammami, R., Beaulieu, L., \& Fliss, I. (2015). Purification and characterization of four antibacterial peptides from protamex hydrolysate of Atlantic mackerel (Scomber scombrus) by-products. Biochemical and Biophysical Research Communications, 462(3), 195200.

Escárcega-Galaz, A. A., López-Cervantes, J., Sánchez-Machado,
D. I., Brito-Zurita, O. R., \& Campas-Baypoli, O. N. (2017). Antimicrobial activity of chitosan membranes against Staphylococcus aureus of clinical origin. In The Rise of Virulence and Antibiotic Resistance in Staphylococcus aureus: IntechOpen.

Fall, P.-A., Leroi, F., Cardinal, M., Chevalier, F., \& Pilet, M.-F. (2010). Inhibition of Brochothrix thermosphacta and sensory improvement of tropical peeled cooked shrimp by Lactococcus piscium CNCM 1-4031. Letters in Applied Microbiology, 50(4), 357-361.

Fan, W., Sun, J., Chen, Y., Qiu, J., Zhang, Y., \& Chi, Y. (2009). Effects of chitosan coating on quality and shelf life of silver carp during frozen storage. Food chemistry, 115(1), 66-70.

FAO. (2014). The state of world fisheries and aquaculture. Retrieved from Rome:

FAO. (2018). The State of World Fisheries and Aquaculture 2018-Meeting the sustainable development goals. Rome, 2018.

Fernandes, J. C., Tavaria, F. K., Fonseca, S. C., Ramos, Ó. S., Pintado, M. E., \& Malcata, F. X. (2010). In vitro screening for anti-microbial activity of chitosans and chitooligosaccharides, aiming at potential uses in functional textiles. Journal of Microbiology and Biotechnology, 20(2), 311-318.

Fernandes, J. C., Tavaria, F. K., Soares, J. C., Ramos, Ó. S., Monteiro, M. J., Pintado, M. E., \& Malcata, F. X. (2008). Antimicrobial effects of chitosans and chitooligosaccharides, upon Staphylococcus aureus and Escherichia coli, in food model systems. Food Microbiology, 25(7), 922-928.

Ghaly, A. E., Dave, D., Budge, S., \& Brooks, M. (2010). Fish spoilage mechanisms and preservation techniques. American Journal of Applied Sciences, 7(7), 859.

Gómez-Estaca, J., Calvo, M. M., Álvarez-Acero, I., Montero, P., \& Gómez-Guillén, M. C. (2017). Characterization and storage stability of astaxanthin esters, fatty acid profile and $\alpha$-tocopherol of lipid extract from shrimp ( $L$. vannamei) waste with potential applications as food ingredient. Food Chemistry, 216, 37-44.

Gonçalves, A. A., \& de Oliveira, A. R. M. (2016). Melanosis in crustaceans: A review. LWT-Food Science and Technology, 65, 791-799.

Goy, R. C., Britto, D. d., \& Assis, O. B. (2009). A review of the antimicrobial activity of chitosan. Polímeros, 19(3), 241247.

Gram, L., \& Dalgaard, P. (2002). Fish spoilage bacteria problems and solutions. Current Opinion in Biotechnology, 13(3), 262-266.

Gram, L., \& Huss, H. H. (1996). Microbiological spoilage of fish and fish products. International Journal of Food Microbiology, 33(1), 121-137.

Groenink, J., Walgreen-Weterings, E., van't Hof, W., Veerman, E. C., \& Nieuw Amerongen, A. V. (1999). Cationic amphipathic peptides, derived from bovine and human lactoferrins, with antimicrobial activity against oral pathogens. FEMS Microbiology Letters, 179(2), 217-222.

Gulzar, S., \& Benjakul, S. (2019). Effect of pre-treatments on yield and properties of lipid extracted from cephalothorax of Pacific white shrimp (Litopenaeus vannamei) by ultrasonic assisted process. LWT, 100, 106113.

Gumgumjee, N. M., Shiekh, H. M., \& Danial, E. N. (2018). Antioxidant and antibacterial activity of chitin, chitosan and shrimp shells from red sea for pharmaceutical uses. 
International Journal of Pharmaceutical Research and Allied Sciences, 7(1).

Hafsa, J., Smach, M. A., Charfeddine, B., Limem, K., Majdoub, H., \& Rouatbi, S. (2016). Antioxidant and antimicrobial proprieties of chitin and chitosan extracted from Parapenaeus longirostris shrimp shell waste. Annales Pharmaceutiques Françaises, 74(1), 27-33.

Hajji, S., Younes, I., Rinaudo, M., Jellouli, K., \& Nasri, M. (2015). Characterization and in vitro evaluation of cytotoxicity, antimicrobial and antioxidant activities of chitosans extracted from three different marine sources. Applied Biochemistry and Biotechnology, 177(1), 18-35.

Harnedy, P. A., \& FitzGerald, R. J. (2012). Bioactive peptides from marine processing waste and shellfish: A review. Journal of Functional Foods, 4(1), 6-24.

Harris, F., Dennison, S. R., \& Phoenix, D. A. (2009). Anionic antimicrobial peptides from eukaryotic organisms. Current Protein and Peptide Science, 10(6), 585-606.

Hassan, M. A., Omer, A. M., Abbas, E., Baset, W. M., \& Tamer, T. M. (2018). Preparation, physicochemical characterization and antimicrobial activities of novel two phenolic chitosan Schiff base derivatives. Scientific Reports, 8(1), 11416.

Hayashi, M., Bizerra, F., \& Da Silva Junior, P. I. (2013). Antimicrobial compounds from natural sources. Frontiers in Microbiology, 4(195).

Hooshmand, H., Shabanpour, B., Moosavi-Nasab, M., \& Golmakani, M. T. (2017). Optimization of carotenoids extraction from blue crab (Portunus pelagicus) and shrimp (Penaeus semisulcatus) wastes using organic solvents and vegetable oils. Journal of Food Processing and Preservation, 41(5), e13171.

Hosomi, R., Yoshida, M., \& Fukunaga, K. (2012). Seafood consumption and components for health. Global Journal of Health Science, 4(3), 72.

Hu, Y., Shang, H., Tong, H., Nehlich, O., Liu, W., Zhao, C., Yu, J., Wang, C., Trinkaus, E., \& Richards, M. P. (2009). Stable isotope dietary analysis of the Tianyuan 1 early modern human. Proceedings of the National Academy of Sciences, 106(27), 10971-10974.

Huang, Y., Huang, J., \& Chen, Y. (2010). Alpha-helical cationic antimicrobial peptides: relationships of structure and function. Protein and Cell, 1(2), 143-152.

Hussein, G., Sankawa, U., Goto, H., Matsumoto, K., \& Watanabe, H. (2006). Astaxanthin, a carotenoid with potential in human health and nutrition. Journal of Natural Products, 69(3), 443-449.

Imjongjirak, C., Amparyup, P., \& Tassanakajon, A. (2011). Two novel antimicrobial peptides, arasin-likeSp and GRPSp, from the mud crab Scylla paramamosain, exhibit the activity against some crustacean pathogenic bacteria. Fish and Shellfish Immunology, 30(2), 706-712.

Irna, C., Jaswir, I., Othman, R., \& Jimat, D. (2017). Antioxidant and antimicrobial activities of astaxanthin from Penaeus monodon in comparison between chemical extraction and High Pressure Processing (HPP). International Food Research Journal, 24, 508-513.

Islam, S., Bhuiyan, M. R., \& Islam, M. (2017). Chitin and chitosan: structure, properties and applications in biomedical engineering. Journal of Polymers and the Environment, 25(3), 854-866.

Jenssen, H., Hamill, P., \& Hancock, R. E. (2006). Peptide antimicrobial agents. Clinical Microbiology Reviews, 19(3), 491-511.
Jeyakumari, A., George, N., Joshy, C. G., Parvathy, U., Zynudheen, A. A., \& Lalitha, K. V. (2016). Effect of chitosan on shelf life of restructured fish products from pangasius (Pangasianodon hypophthalmus) surimi during chilled storage. Journal of Food Science and Technology, 53(4), 2099-2107.

Juturu, V., \& Wu, J. C. (2018). Microbial production of bacteriocins: Latest research development and applications. Biotechnology Advances, 36(8), 2187-2200.

Kandra, P., Challa, M. M., \& Jyothi, H. K. P. (2012). Efficient use of shrimp waste: present and future trends. Applied Microbiology and Biotechnology, 93(1), 17-29.

Kuley, E., Durmus, M., Balikci, E., Ucar, Y., Regenstein, J. M., \& Özoğul, F. (2017). Fish spoilage bacterial growth and their biogenic amine accumulation: Inhibitory effects of olive by-products. International Journal of Food Properties, 20(5), 1029-1043.

Kumar, P., Kizhakkedathu, J. N., \& Straus, S. K. (2018). Antimicrobial peptides: Diversity, mechanism of action and strategies to improve the activity and biocompatibility in vivo. Biomolecules, 8(1), 4.

Kurniasih, M., \& Dewi, R. (2018). Toxicity tests, antioxidant activity, and antimicrobial activity of chitosan. Paper presented at the IOP Conference Series: Materials Science and Engineering.

Laokuldilok, T., Potivas, T., Kanha, N., Surawang, S., Seesuriyachan, P., Wangtueai, S., Phimolsiripol, Y., \& Regenstein, J. M. (2017). Physicochemical, antioxidant, and antimicrobial properties of chitooligosaccharides produced using three different enzyme treatments. Food Bioscience, 18, 28-33.

León-Calvijo, M. A., Leal-Castro, A. L., Almanzar-Reina, G. A., Rosas-Pérez, J. E., García-Castañeda, J. E., \& RiveraMonroy, Z. J. (2015). Antibacterial activity of synthetic peptides derived from lactoferricin against Escherichia coli ATCC 25922 and Enterococcus faecalis ATCC 29212. BioMed Research International, 2015.

Li, T., Hu, W., Li, J., Zhang, X., Zhu, J., \& Li, X. (2012). Coating effects of tea polyphenol and rosemary extract combined with chitosan on the storage quality of large yellow croaker (Pseudosciaena crocea). Food Control, 25(1), 101-106.

Li, T., Li, J., Hu, W., \& Li, X. (2013). Quality enhancement in refrigerated red drum (Sciaenops ocellatus) fillets using chitosan coatings containing natural preservatives. Food Chemistry, 138(2), 821-826.

Liang, S., Sun, Y., \& Dai, X. (2018). A review of the preparation, analysis and biological functions of chitooligosaccharide. International Journal of Molecular Sciences, 19(8), 2197.

Liao, I.-C., \& Chao, N.-H. (2009). Aquaculture and food crisis: opportunities and constraints. Asia Pacific Journal of Clinical Nutrition, 18(4), 564-569.

Liaqat, F., \& Eltem, R. (2018). Chitooligosaccharides and their biological activities: a comprehensive review. Carbohydrate Polymers, 184, 243-259.

Lidbury, I., Murrell, J. C., \& Chen, Y. (2014). Trimethylamine Noxide metabolism by abundant marine heterotrophic bacteria. Proceedings of the National Academy of Sciences, 111(7), 2710-2715.

Linares, D. M., Gomez, C., Renes, E., Fresno, J. M., Tornadijo, M. E., Ross, R. P., \& Stanton, C. (2017). Lactic acid bacteria and bifidobacteria with potential to design natural biofunctional health-promoting dairy foods. Frontiers in Microbiology, 8, 846. 
Lodhi, G., Kim, Y.-S., Hwang, J.-W., Kim, S.-K., Jeon, Y.-J., Je, J.Y., Ahn, C.-B., Moon, S.-H., Jeon, B.-T., \& Park, P.-J. (2014). Chitooligosaccharide and its derivatives: preparation and biological applications. BioMed Research International, 2014.

Mahae, N., Chalat, C., \& Muhamud, P. (2011). Antioxidant and antimicrobial properties of chitosan-sugar complex. International Food Research Journal, 18(4).

Mahdy Samar, M., El-Kalyoubi, M. H., Khalaf, M. M., \& Abd ElRazik, M. M. (2013). Physicochemical, functional, antioxidant and antibacterial properties of chitosan extracted from shrimp wastes by microwave technique. Annals of Agricultural Sciences, 58(1), 33-41.

Mahlapuu, M., Håkansson, J., Ringstad, L., \& Björn, C. (2016). Antimicrobial peptides: An emerging category of therapeutic agents. Frontiers in Cellular and linfection Microbiology, 6, 194-194.

Mantravadi, P. K., Kalesh, K. A., Dobson, R. C., Hudson, A. O., \& Parthasarathy, A. (2019). The quest for novel antimicrobial compounds: emerging trends in research, development, and technologies. Antibiotics, 8(1), 8.

Mohan, C. O., Ravishankar, C. N., Lalitha, K. V., \& Srinivasa Gopal, T. K. (2012). Effect of chitosan edible coating on the quality of double filleted Indian oil sardine (Sardinella longiceps) during chilled storage. Food Hydrocolloids, 26(1), 167-174.

Moosavi-Nasab, M., Shad, E., Ziaee, E., Yousefabad, S. H. A., Golmakani, M. T., \& Azizinia, M. (2016). Biodegradable chitosan coating incorporated with black pepper essential oil for shelf life extension of common carp (Cyprinus carpio) during refrigerated storage. Journal of Food Protection, 79(6), 986-993.

Moravej, H., Moravej, Z., Yazdanparast, M., Heiat, M., Mirhosseini, A., Moghaddam, M. M., \& Mirnejad, R. (2018). Antimicrobial peptides: features, action, and their resistance mechanisms in bacteria. Microbial Drug Resistance, 24(6), 747-767.

Najafian, L., \& Babji, A. S. (2012). A review of fish-derived antioxidant and antimicrobial peptides: their production, assessment, and applications. Peptides, 33(1), 178-185.

Ojagh, S. M., Rezaei, M., Razavi, S. H., \& Hosseini, S. M. H. (2010). Effect of chitosan coatings enriched with cinnamon oil on the quality of refrigerated rainbow trout. Food Chemistry, 120(1), 193-198.

Olatunde, O. O., \& Benjakul, S. (2020). Antioxidants from crustaceans: A panacea for lipid oxidation in marinebased foods. Food Reviews International, 1-31.

Olatunde, O. O., Benjakul, S., \& Vongkamjan, K. (2018). Antioxidant and antibacterial properties of guava leaf extracts as affected by solvents used for prior dechlorophyllization. Journal of Food Biochemistry, 42(5), e12600.

Olatunde, O. O., Benjakul, S., \& Vongkamjan, K. (2019). Comparative study on nitrogen and argon-based modified atmosphere packaging on microbiological, chemical, and sensory attributes as well as on microbial diversity of Asian sea bass. Food Packaging and Shelf Life, 22, 100404.

Perez Espitia, P. J., de Fátima Ferreira Soares, N., dos Reis Coimbra, J. S., de Andrade, N. J., Souza Cruz, R., Medeiros, A., \& Antonio, E. (2012). Bioactive peptides: synthesis, properties, and applications in the packaging and preservation of food. Comprehensive Reviews in Food Science and Food Safety, 11(2), 187-204.
Pilantanapak, A., Waiprib, Y., Eadtem, P., \& Panbangred, W. (2017). Production of chitooligosaccharides with antibacterial potential via crude chitinase enzymes from marine fungi. Chiang Mai Journal of Science, 44(4), 12241230.

Poonsin, T., Simpson, B. K., Benjakul, S., Visessanguan, W., Yoshida, A., \& Klomklao, S. (2018). Carotenoprotein from Pacific white shrimp (Litopenaeus vannamei) shells extracted using trypsin from albacore tuna (Thunnus alalunga) spleen: Antioxidant activity and its potential in model systems. Journal of Food Biochemistry, 42(2), e12462.

Prabu, K., \& Natarajan, E. (2012). In vitro antimicrobial and antioxidant activity of chitosan isolated from Podophthalmus vigil. Journal of Applied Pharmaceutical Science, 2(9), 75.

Priya, E., Rethna, , Ravichandran, S., \& Jawaharlal, P. (2014). Antimicrobial and antioxidant proteins from the crab Lliagore rubromaculata (De Haan, 1835). World Journal of Pharmacy and Pharmaceutical Sciences, 3(10), 533541.

Pu, J., Bankston, J. D., \& Sathivel, S. (2011). Production of microencapsulated crawfish (Procambarus clarkii) astaxanthin in oil by spray drying technology. Drying Technology, 29(10), 1150-1160.

Ragab, T. I., El-Bassyouni, G. T., Helmy, W. A., Taie, H. A., Refaat, A., Ibrahim, M. A., El-Hmeed, E. A., \& Esawy, M. A. (2018). Evaluation of multifunction bioactivities of extracted chitosan and their uv/ozone derivatives. Journal of Applied Pharmaceutical Science, 8(10), 053062.

Rajalakshmi, A., Krithiga, N., \& Jayachitra, A. (2013). Antioxidant activity of the chitosan extracted from shrimp exoskeleton. Middle-East Journal of Scientific Research, 16(10), 1446-1451.

Raju, N., \& Benjakul, S. (2020). Use of beta cyclodextrin to remove cholesterol and increase astaxanthin content in shrimp oil. European Journal of Lipid Science and Technology, 122(2), 1900242.

Ramírez-Guerra, H., Castillo-Yañez, F., Montaño-Cota, E., RuízCruz, S., Márquez-Ríos, E., Canizales-Rodríguez, D., Torres-Arreola, W., Montoya-Camacho, N., \& OcañoHiguera, V. (2018). Protective effect of an edible tomato plant extract/chitosan coating on the quality and shelf life of Sierra fish fillets. Journal of Chemistry, 2018.

Reynisson, E., Lauzon, H. L., Magnússon, H., Jónsdóttir, R., Ólafsdóttir, G., Marteinsson, V., \& Hreggviðsson, G. Ó. (2009). Bacterial composition and succession during storage of North-Atlantic cod (Gadus morhua) at superchilled temperatures. BMC Microbiology, 9(1), 250.

Richards, M. P., \& Trinkaus, E. (2009). Isotopic evidence for the diets of European Neanderthals and early modern humans. Proceedings of the National Academy of Sciences, 106(38), 16034-16039.

Riedl, S., Zweytick, D., \& Lohner, K. (2011). Membrane-active host defense peptides-challenges and perspectives for the development of novel anticancer drugs. Chemistry and Physics of Lipids, 164(8), 766-781.

Rinaudo, M. (2006). Chitin and chitosan: properties and applications. Progress in polymer science, 31(7), 603 632.

Robert, M., Zatylny-Gaudin, C., Fournier, V., Corre, E., Le Corguillé, G., Bernay, B., \& Henry, J. (2015). Molecular characterization of peptide fractions of a Tilapia (Oreochromis niloticus) by-product hydrolysate and in 
vitro evaluation of antibacterial activity. Process Biochemistry, 50(3), 487-492.

Sabaa, M. W., Elzanaty, A. M., Abdel-Gawad, O. F., \& Arafa, E. G. (2018). Synthesis, characterization and antimicrobial activity of Schiff bases modified chitosan-graftpoly(acrylonitrile). International Journal of Biological Macromolecules, 109, 1280-1291.

Sachindra, N. M., \& Mahendrakar, N. S. (2011). Effect of protease treatment on oil extractability of carotenoids from shrimp waste. Journal of Aquatic Food Product Technology, 20(1), 22-31.

Santos-Moriano, P., Kidibule, P., Míguez, N., Fernández-Arrojo, L., Ballesteros, A., Fernández-Lobato, M., \& Plou, F. (2019). Tailored enzymatic synthesis of chitooligosaccharides with different deacetylation degrees and their anti-inflammatory activity. Catalysts, 9(5), 405.

Sathiyabama, M., \& Parthasarathy, R. (2016). Biological preparation of chitosan nanoparticles and its in vitro antifungal efficacy against some phytopathogenic fungi. Carbohydrate Polymers, 151, 321-325.

Sayari, N., Sila, A., Abdelmalek, B. E., Abdallah, R. B., EllouzChaabouni, S., Bougatef, A., \& Balti, R. (2016). Chitin and chitosan from the Norway lobster by-products: Antimicrobial and anti-proliferative activities. International Journal of Biological Macromolecules, 87, 163-171.

Sebti, I., Martial-Gros, A., Carnet-Pantiez, A., Grelier, S., \& Coma, V. (2005). Chitosan polymer as bioactive coating and film against Aspergillus niger contamination. Journal of Food Science, 70(2), M100-M104.

Senphan, T., Benjakul, S., \& Kishimura, H. (2014). Characteristics and antioxidative activity of carotenoprotein from shells of Pacific white shrimp extracted using hepatopancreas proteases. Food Bioscience, 5, 54-63.

Shin, S. C., Ahn, I. H., Ahn, D. H., Lee, Y. M., Lee, J., Lee, J. H., Kim, H.-W., \& Park, H. (2017). Characterization of two antimicrobial peptides from antarctic fishes (Notothenia coriiceps and Parachaenichthys charcoti). PloS One, 12(1), e0170821.

Sila, A., Ayed-Ajmi, Y., Sayari, N., Nasri, M., Martínez-Alvarez, O., \& Bougatef, A. (2013). Antioxidant and antiproliferative activities of astaxanthin extracted from the shell waste of deep-water pink shrimp (Parapenaeus longirostris). Journal of Natural Products, 3, 82-89.

Sila, A., Hedhili, K., Przybylski, R., Ellouz-Chaabouni, S., Dhulster, P., Bougatef, A., \& Nedjar-Arroume, N. (2014). Antibacterial activity of new peptides from barbel protein hydrolysates and mode of action via a membrane damage mechanism against Listeria monocytogenes. Journal of Functional Foods, 11, 322329.

Silva, A. K. N. d., Rodrigues, B. D., Silva, L. H. M. d., \& Rodrigues, A. M. d. C. (2018). Drying and extraction of astaxanthin from pink shrimp waste (Farfantepenaeus subtilis): the applicability of spouted beds. Food Science and Technology, 38, 454-461.

Sinthusamran, S., Benjakul, S., Kijroongrojana, K., Prodpran, T., \& Agustini, T. W. (2018). Yield and chemical composition of lipids extracted from solid residues of protein hydrolysis of Pacific white shrimp cephalothorax using ultrasound-assisted extraction. Food Bioscience, 26, 169176.

Sivertsvik, M., Jeksrud, W. K., \& Rosnes, J. T. (2002). A review of modified atmosphere packaging of fish and fishery products-significance of microbial growth, activities and safety. International Journal of Food Science \& Technology, 37(2), 107-127.

Sousa, F., Guebitz, G. M., \& Kokol, V. (2009). Antimicrobial and antioxidant properties of chitosan enzymatically functionalized with flavonoids. Process Biochemistry, 44(7), 749-756.

Souza, B. W., Cerqueira, M. A., Ruiz, H. c. A., Martins, J. T., Casariego, A., Teixeira, J. A., \& Vicente, A. A. (2010). Effect of chitosan-based coatings on the shelf life of salmon (Salmo salar). Journal of Agricultural and Food Chemistry, 58(21), 11456-11462.

Sowmya, R., Rathinaraj, K., \& Sachindra, N. M. (2011). An Autolytic Process for Recovery of Antioxidant Activity Rich Carotenoprotein from Shrimp Heads. Marine Biotechnology, 13(5), 918-927.

Suganya, V., \& Asheeba, S. (2015). Antioxidant and antimicrobial activity of astaxanthin isolated from three varietes of crabs. International Journal of Recent Scientific Research, 6(10), 6753-6758.

Takeungwongtrakul, S., \& Benjakul, S. (2016). Astaxanthin degradation and lipid oxidation of Pacific white shrimp oil: kinetics study and stability as affected by storage conditions. International Aquatic Research, 8(1), 15-27.

Thaker, M., Hanjabam, M. D., Gudipati, V., \& Kannuchamy, N. (2017). Protective effect of fish gelatin-based natural antimicrobial coatings on quality of Indian salmon fillets during refrigerated storage. Journal of Food Process Engineering, 40(1), e12270-12280.

Tikk, M., Tikk, K., Tørngren, M. A., Meinert, L., Aaslyng, M. D., Karlsson, A. H., \& Andersen, H. J. (2006). Development of inosine monophosphate and its degradation products during aging of pork of different qualities in relation to basic taste and retronasal flavor perception of the meat. Journal of Agricultural and Food Chemistry, 54(20), 77697777.

Varlet, V., \& Fernandez, X. (2010). Sulfur-containing volatile compounds in seafood: occurrence, odorant properties and mechanisms of formation. Food Science and Technology International, 16(6), 463-503.

Varun, T. K., Senani, S., Jayapal, N., Chikkerur, J., Roy, S., Tekulapally, V. B., Gautam, M., \& Kumar, N. (2017). Extraction of chitosan and its oligomers from shrimp shell waste, their characterization and antimicrobial effect. Veterinary world, 10(2), 170-175.

Visciano, P., Schirone, M., Tofalo, R., \& Suzzi, G. (2012). Biogenic amines in raw and processed seafood. Frontiers in Microbiology, 3, 188.

Wald, M., Schwarz, K., Rehbein, H., Bußmann, B., \& Beermann, C. (2016). Detection of antibacterial activity of an enzymatic hydrolysate generated by processing rainbow trout by-products with trout pepsin. Food Chemistry, 205, 221-228.

Wang, Y., Zhou, P.-G., Yu, J.-X., Pan, X.-R., Wang, P.-P., Lan, W.Q., \& Tao, S.-D. (2007). Antimicrobial effect of chitooligosaccharides produced by chitosanase from Pseudomonas CUY8. Asia Pacific Journal of Clinical Nutrition, 16(S1), 174-177.

Wenjiao, F., Yongkui, Z., Pan, D., \& Yuwen, Y. (2013). Effects of chitosan coating containing antioxidant of bamboo leaves on qualitative properties and shelf life of silver carp during chilled storage. Czech Journal of Food Sciences, 31(5), 451-456.

WHO. (2013). World Health Organization. Global tuberculosis 
report 2013: World Health Organization.

Xin, Y., Zhao, H., Xu, J., Xie, Z., Li, G., Gan, Z., \& Wang, X. (2020). Borneol-modified chitosan: Antimicrobial adhesion properties and application in skin flora protection. Carbohydrate Polymers, 228, 115378.

Yağin, C., \& Büyükyörük, S. (2017). The effects of chitosan, sodium lactate and sodium diacetate on the shelf life of hot smoked and vacuum packed rainbow trout fillets. Ankara Üniversitesi Veteriner Fakültesi Dergisi, 64(1), 16.

Yang, S.-C., Lin, C.-H., Sung, C. T., \& Fang, J.-Y. (2014). Antibacterial activities of bacteriocins: Application in foods and pharmaceuticals. Frontiers in Microbiology, 5, 241-241.

Ye, Y., Barange, M., Beveridge, M., Garibaldi, L., Gutierrez, N., Anganuzzi, A., \& Taconet, M. (2017). FAO's statistic data and sustainability of fisheries and aquaculture: Comments on Pauly and Zeller (2017). Marine Policy, 81, 401-405.

Younes, I., Hajji, S., Frachet, V., Rinaudo, M., Jellouli, K., \& Nasri, M. (2014). Chitin extraction from shrimp shell using enzymatic treatment. Antitumor, antioxidant and antimicrobial activities of chitosan. International Journal of Biological Macromolecules, 69, 489-498.

Zaman, N. B. K., Lin, N. K., \& Phing, P. L. (2018). Chitosan film incorporated with Garcinia atroviridis for the packaging of Indian mackerel (Rastrelliger kanagurta). Ciência $e$ Agrotecnologia, 42(6), 666-675.

Zamora-Sillero, J., Gharsallaoui, A., \& Prentice, C. (2018). Peptides from fish by-product protein hydrolysates and its functional properties: an overview. Marine Biotechnology, 20(2), 118-130.

Zhang, Y.-x., Zou, A.-H., Manchu, R.-G., Zhou, Y.-C., \& Wang, S.f. (2008). Purification and antimicrobial activity of antimicrobial protein from brown-spotted grouper, Epinephelus fario. Journal of Zoological Systematics and Evolutionary Research, 29, 627-632.

Zhao, L., Yin, B., Liu, Q., \& Cao, R. (2013). Purification of antimicrobial peptide from Antarctic Krill (Euphausia superba) and its function mechanism. Journal of Ocean University of China, 12(3), 484-490.

Zimoch-Korzycka, A., Bobak, Ł., \& Jarmoluk, A. (2016). Antimicrobial and antioxidant activity of chitosan/hydroxypropyl methylcellulose film-forming hydrosols hydrolyzed by cellulase. International journal of molecular sciences, 17(9), 1436. 